\title{
PENNSYLVANIAN CONODONT ASSEMBLAGES FROM LA SALLE COUNTY, NORTHERN ILLINOIS
}

\author{
Charles Collinson \\ Matthew J. Avcin \\ Illinois State Geological Survey \\ Rodney D. Norby \\ University of Illinois \\ Glen K. Merrill \\ University of Texas at Arlington
}
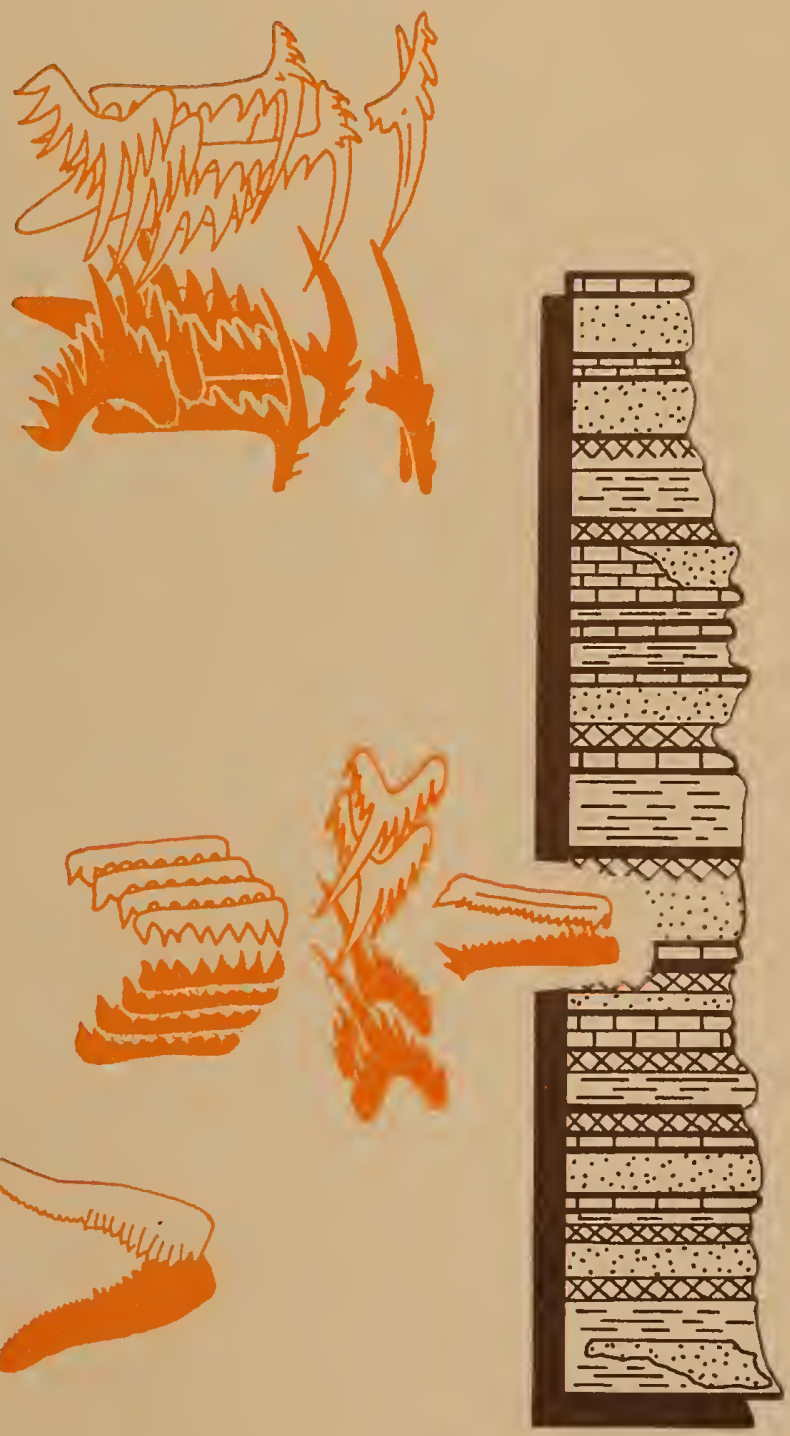

Illinois State Geological Survey Guidebook Series 10 


\section{FIELD TRIP SCHEDULE}

8:00 a.m. Assemble in Parking Lot east of Field House. Depart De Kalb for Starved Rock State Park west of Ottawa by $8: 30 \mathrm{a} . \mathrm{m}$. Do not drive in convoy on this leg of trip.

10:00 a.m. Arrive at Starved Rock State Park. STOP 1. Coffee and donuts.

11:00 a.m. Approximately. Leave STOP 1 in convoy.

11:30 a.m. Arrive at Bailey Falls. STOP 2 .

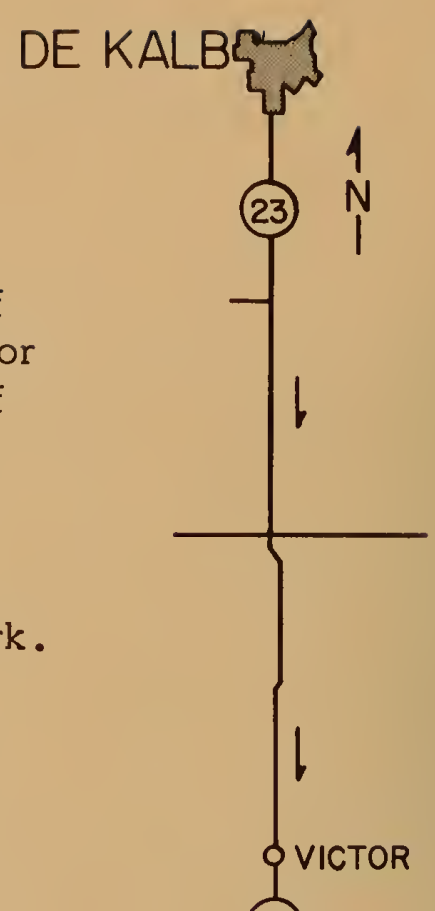

1:00 p.m. LUNCH

2:00 p.m. Open options - return to Bailey Falls or proceed to optional stops.

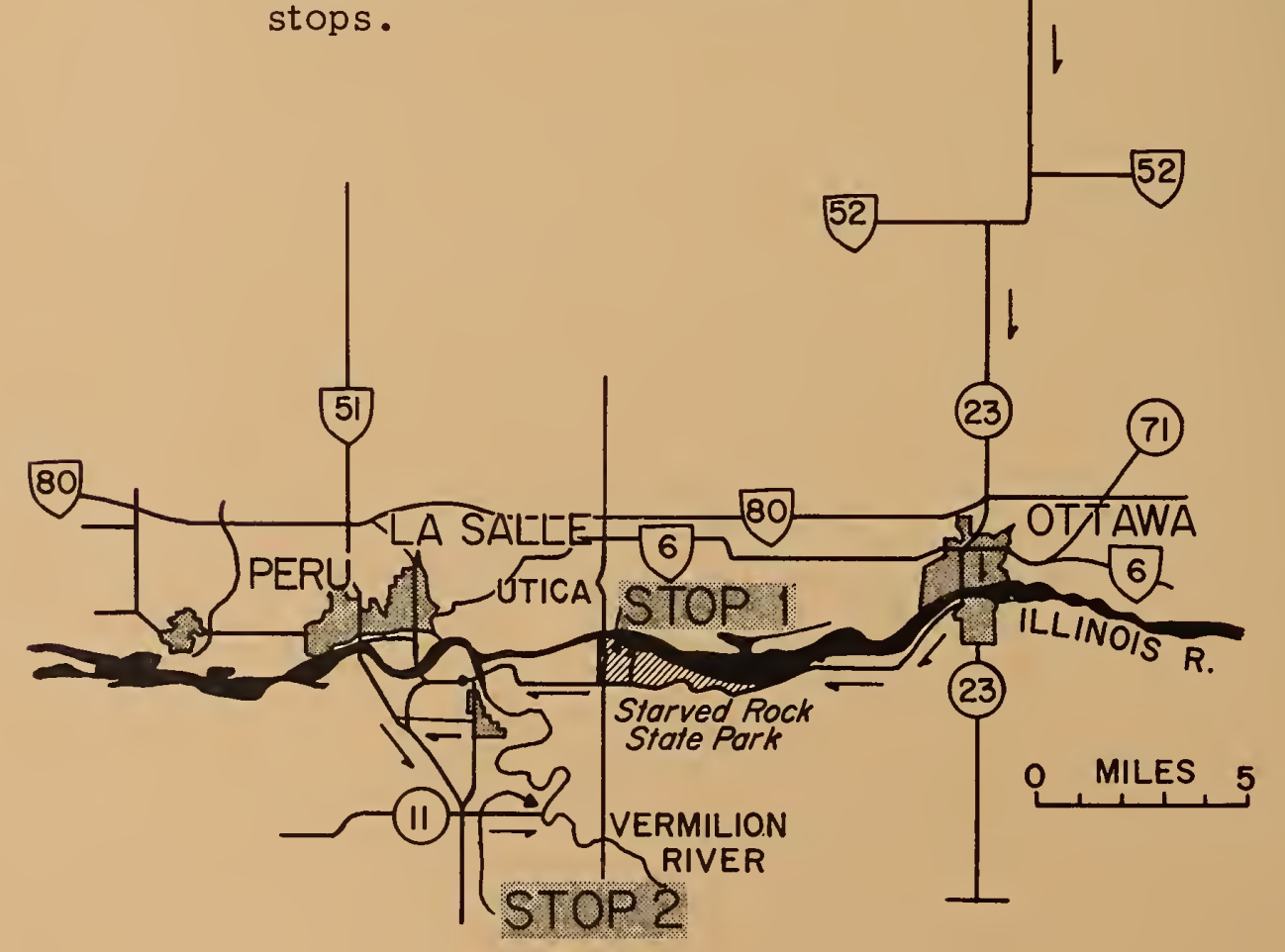




\section{GUIDEBOOK SERIES 10}

Illinois State Geological Survey

\section{PENNSYLVANIAN CONODONT ASSEMBLAGES}

from

\section{LA SALLE COUNTY, NORTHERN ILLINOIS}

CHARLES COLLINSON

MATTHEW J. AVCIN

Illinois State Geological Survey

RODNEY D. NORBY

University of Illinois

GLEN K. MERRILL

University of Texas, Arlington

prepared for annual meeting

PANDER SOCIETY

in cooperation with North-Central Section

THE GEOLOGICAL SOCIETY OF AMERICA

De Kalb, Illinois

May $11-14,1972$ 
Digitized by the Internet Archive in 2012 with funding from University of Illinois Urbana-Champaign 


\title{
PENNSYLVANIAN CONODONT ASSEMBLAGES
}

\author{
from
}

\author{
LA SALLE COUNTY, NORTHERN ILLINOIS
}

\section{INTRODUCTION}

Although more than a dozen reports describing natural assemblages of conodonts have been published, almost none have given sufficient stratigraphic information to enable subsequent workers to visit the collecting sites and be reasonably certain of securing assemblages without considerable investment of time. Because of the coincidence of the Pander Society meeting in De Kalb with the revival of interest in natural assemblages of conodonts and because of the general inaccessibility of all previously collected natural assemblages, we have prepared this guide. The guidebook, however, is mainly a guide to the vicinity of Bailey Falls (figs. 1 and 2), which is the topotype locality for Scottognathus and Duboisella and the most prolific assemblage collecting locality known outside of Scott's Heath locality in Montana. Glen Merrill (Lane, Merrill, Straka, and Webster, 1971) has recognized examples of his Midcontinent and Appalachian biofacies faunas in the Bailey Falls section also and has identified more than a dozen genera and nearly 50 partial species in the limestones near the falls.

In order to further our primary purpose of making natural assemblages generally available for classroom and research use, we have included a number of sections as optional stops near the end of the guidebook. Two are local variations of the Bailey Falls section, three are sections from older parts of the Pennsylvanian (fig. 3) in northern Illinois, and two are additional localities of Rhodes (localities 7 and 2 [Rhodes, 1952] from Adams and Macoupin Counties in western Illinois respectively). All have yielded abundant faunas and the last have also yielded assemblages. The Adams County locality is also the topotype locality of Illinella Rhodes, 1952. The last pages in the guidebook show an optional-1ocality map (fig. 11) and small inset maps (fig. 12) taken from quadrangle topographic sheets which will guide you to any of the optional localities you wish to visit.

\section{ACKNOWLEDGMENTS}

We are greatly indebted to the Marquette Cement Manufacturing Company for permission to enter their property and to Mr. Henry Janz, Township Road Commissioner, for access to Bailey Falls along the extension of Bailey Falls Road. Dr. and Mrs. Hugh Black of Bailey Falls Road were both gracious and helpful, especially during early stages of planning. We have drawn heavily on $\mathrm{H}$. B. Willman's intimate knowledge of the La Salle area and on Illinois Geological Survey Field Guidebook Series 8, which covers much of the same area. Persons who have directly contributed their labors to the success of the field trip are Margaret Whaley, Mildred Newhouse, Susan Avcin, Dr. Lois Kent, Patricia Perkins, and James Rogers. We are grateful to all. 


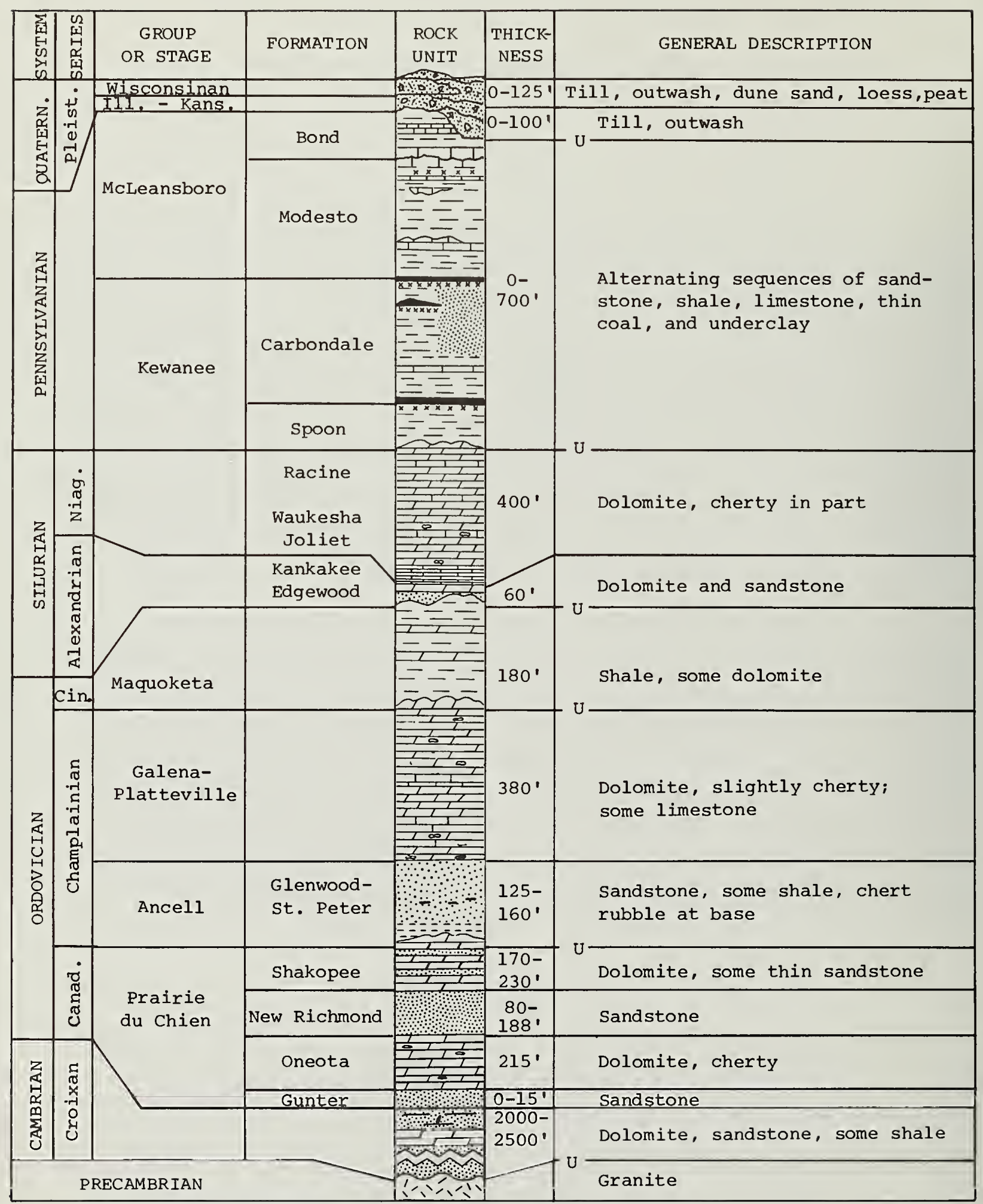

Fig. 1 - Generalized geologic column in the La Salle area. "U" indicates a major unconformity. See figure 3 for a detailed Pennsylvanian column. 


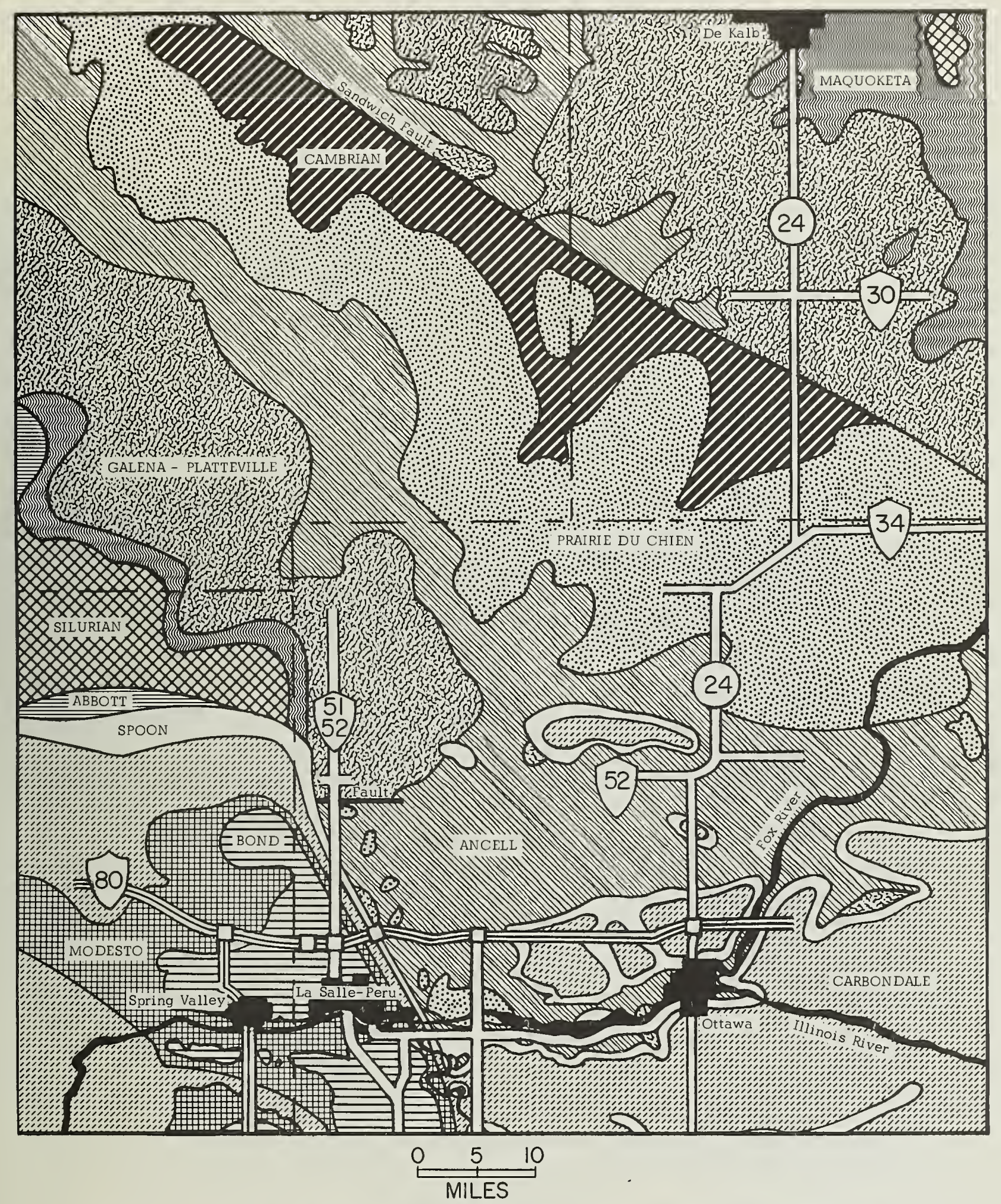

Fig. 2 - Geology and route map of field trip area, modified from Illinois State Geological Survey Geologic Map of Illinois (Willman and others, 1967). 


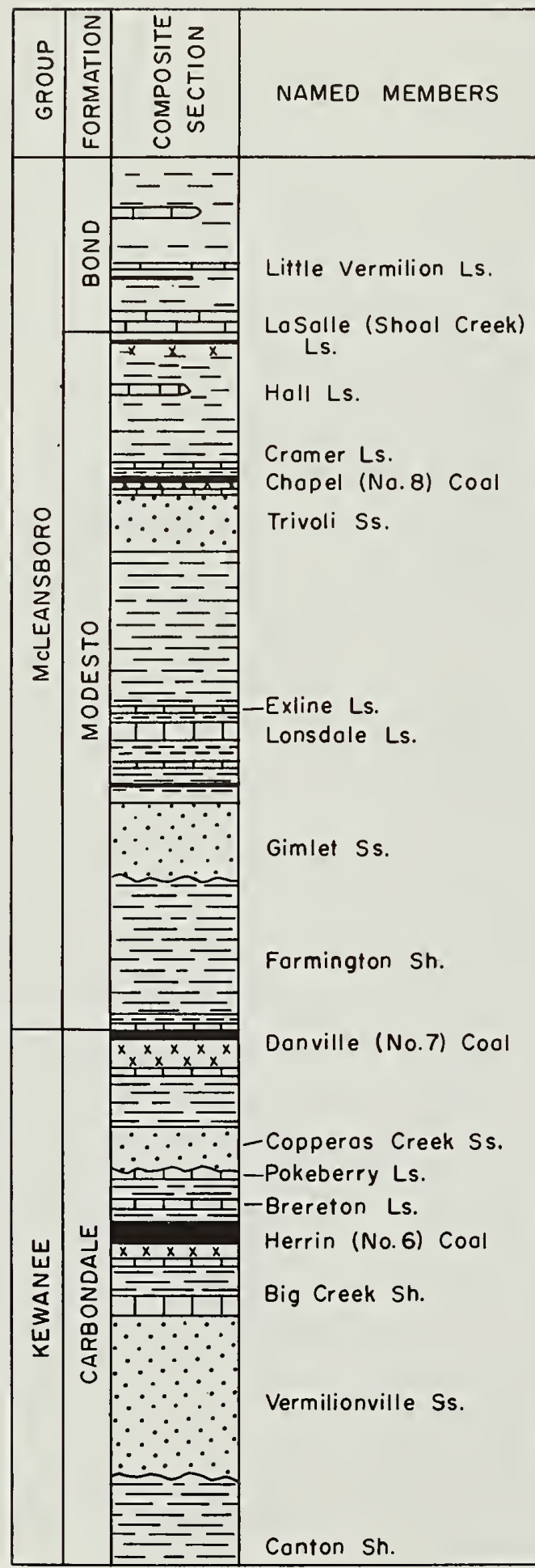

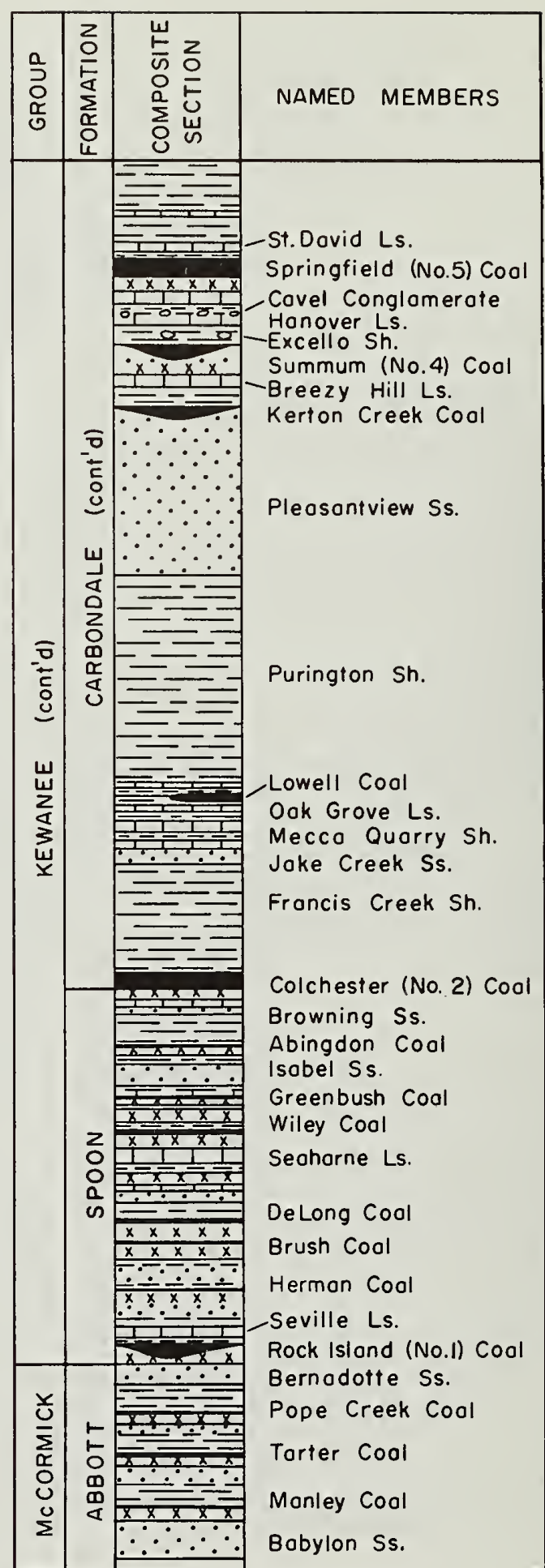

Approximate Scale in Feet

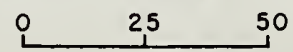

Fig. 3 - Columnar section of Pennsylvanian strata in northern and western Illinois from Smith et al., 1970. 
ROAD LOG

DE KALB TO STARVED ROCK STATE PARK

SATURDAY, MAY 13, 1972

Leaders: Charles Collinson, Matthew J. Avcin, Rodney D. Norby, Glen K. Merrill

Meet in parking lot east of Northern Illinois University Field House, where participants needing transportation can find rides. When filled, automobiles should proceed independently to the main parking lot on the river bottom at Starved Rock State Park. DO NOT TRAVEL IN CONVOY ON THIS LEG OF THE TRIP! DRIVE SAFELY!

Mile 00.00 on the road $\log$ will begin at the intersection of U.S. Interstate 80 and Illinois Route 23 just north of 0ttawa-40 miles almost due south of De Kalb. Log mileage given is only approximate. To leave De Kalb, leave the parking lot by turning right (south) on University Circle Drive. University Circle swings eastward near the University School and joins Carroll Avenue approximately a block and a half to the east. Turn right (south) on Carroll Avenue and go $1 / 2$ block on Lincoln Highway (U.S. Route 30). Turn left (east) on Lincoln Highway. Travel approximately $1 / 2$ mile to its junction with Illinois Route 23. Turn right (south) on Route 23, which will take you directly to Ottawa. See route map and time schedule on inside front cover.

Checkpoints, measured from the south city limits of De Kalb, are: U.S. Route 30 at 10 miles, village of Victor at 18 miles, junction with U.S. Route 34 at 22 miles, junction with U.S. Route 52 at 32 miles, and junction with U.S. Interstate Route 80 at 40 miles (start road 1 og at crossover with Interstate 80 ).

Virtually the entire route to Ottawa will be made over Pleistocene (Wisconsinan) groundmoraine. Only two morainal ridge belts will be crossed. The first, the northeast-southwest trending Shabbona-Arlington-Mendota morainal complex, will be encountered about 4 miles south of De Kalb (near the junction of Route 23 and the Milan road). It accounts for the undulating topography for the next 6 miles. Sixteen miles south of De Kalb, the Farm Ridge Moraine trends northeast-southwest and forms a four-mile wide belt which extends to the village of Victor. South of the Farm Ridge Moraine to the Illinois Valley at Ottawa, the route is on the flat plain of Lake Ottawa, an upland area flooded by the glacial meltwater from the Kankakee Flood. The flood resulted about 14,000 years ago when glacial ice from the Erie glacial lobe blocked a discharge route to the Wabash Valley on the southeast and meltwater from the Erie, Lake Michigan, and Saginaw glacial lobes concentrated in the drainage systems of the Kankakee and Illinois Rivers.

Mileage

$00.00 \quad 00.00$ Overpass of Route 23 over Interstate 80 . Continue straight ahead (south). 
00.4000 .40 Enter Ottawa. Descend hill on curving road to level of Pleistocene (Wisconsinan) terraces in the Illinois River Valley. Terraces flooring the valley were cut by the outlet River of Lake Chicago.

01.5001 .10 Junction of Route 23 with Illinois Route 71 and U.S. Route 6 (Norris Street). Continue straight ahead.

01.7000 .20 Turn right on Michigan Street (one-way west).

01.7500 .05 DANGEROUS INTERSECTION. Turn left on La Salle Street (oneway south). Continue south through business district (5 stop lights).

02.3500 .60 La Salle Street turns left $45^{\circ}$ onto Illinois River Bridge.

02.70 00.35 DANGEROUS INTERSECTION. Turn right (west) at junction of Illinois Routes 23 and 71 at south end of bridge. Route 23 continues southward. We will continue on Route 71 (westward). Follow Hitt Street, passing Allen Park on the right. Just west of Ottawa, the lower three-fourths of the Illinois Valley walls are composed of Pennsylvanian sediments while upper parts consist of glacial drift.

03.0000 .30 Chicago, Burlington \& Quincy railroad tracks. Sandstone of the Ordovician St. Peter Formation is exposed on the north bank of the river.

03.30 00.30 Large wat $\epsilon$-filled silica sand pit on left. The St. Peter is widely known as a glass sand but is also used for foundry sand, abrasives, silica brick, ceramic glazes, and ferrosilicon. It is also used for fracture treatment of oil-bearing formations to increase flow. Illinois ranks No. 1 in the United States in glass sand production, and virtually all is provided by the St. Peter of La Salle and Ogle Counties.

03.9000 .60 Another water-filled pit on left.

$04.70 \quad 00.80$ Quarry refuse on right bank of river.

$05.50 \quad 00.80$ Cross Covel Creek. Sandstone of the St. Peter with dolomite of the Platteville Group on top of it can be seen on both sides of the road. Westward, beyond Covel Creek, the bluffs are almost entirely bedrock. Approximately 1 mile west of here, the top of the St. Peter appears at the base of the bluff. Westward from there, the sandstone climbs the cliffs and reaches the top in Starved Rock State Park.

06.1000 .60 We are crossing the broad, flat 0ttawa Terrace, which lies between the inner channel of the Illinois River and the uplands seen on the south. The terrace here is a bedrock bench cut on the top of the St. Peter, which is covered by only a few feet of soil, sand, and gravel. The Ottawa Terrace records downcutting of some 50 feet by overflow of glacial Lake Chicago. 
06.30 00.20 Waste piles ahead on the far right are strippings from mining of the Colchester (No. 2) Coal Member.

06.80 00.50 The picnic area on the right is a separate part of Starved Rock Park called the Ottawa Shelter. The mine-waste piles on the right bank of the river are near the south side of Buffalo Rock near the site of Buffalo Rock State Park, which is reached from the north side of the river.

$07.40 \quad 00.60$ The St. Peter Sandstone is exposed on the right.

$07.80 \quad 00.40$ On the far left, the bluff formed by the St. Peter rises gently westward toward the crest of the La Salle Anticline (the crest lies approximately 7 miles to the west). The bluffs are uniformly about 50 feet in height except at several places in the park where downward cutting of the terraces in the valley bottom has extended the cliffs downward.

08.25 00.45 East Entrance of Starved Rock State Park (see arrows on figure 4).

08.6000 .35 Illinois Canyon on left.

$08.90 \quad 00.30$ Begin ascent of valley wall. SLOW!

09.8000 .90 Hennepin Canyon on right with scenic view of river.

10.85 01.05 La Salle and Horseshoe Canyons on right.

$11.00 \quad 00.15$ Tonti Canyon trail to right. Small parking area. An arched bridge is part of the Tonti Canyon trail.

11.4500 .45 Upland area underlain by Pennsylvanian rocks and Pleistocene surficial materials.

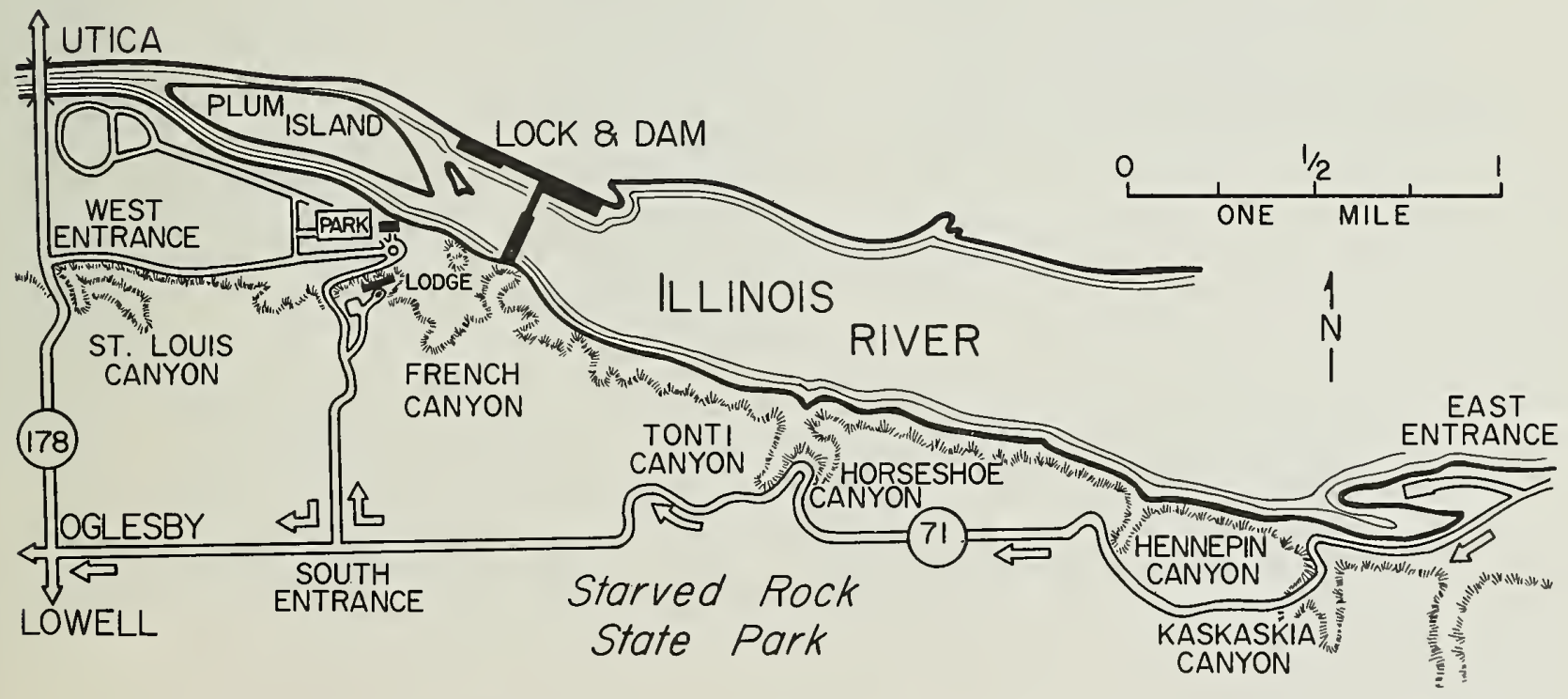

Fig. 4 - Route map through Starved Rock State Park, La Salle County. 
$-8-$

12.15 00.70 Turn right. South Entrance of Starved Rock State Park. Speed 1imit $20 \mathrm{mph}$.

12.6500 .50 Intersection to Starved Rock Lodge on right. Continue ahead. Begin descent of valley wall to valley floor. CAUTION. STEEP HILL.

13.1500 .50 Turn left (west) at bottom of hill.

13.2500 .10 Ranger office on left.

13.35 00.10 Turn right (north) at Campground and Boating parking sign.

13.4000 .10 Turn right (east) into large parking area. Refreshments and personal conveniences are available. Trails to Starved Rock (fig. 5) are east of the convenience stations. 


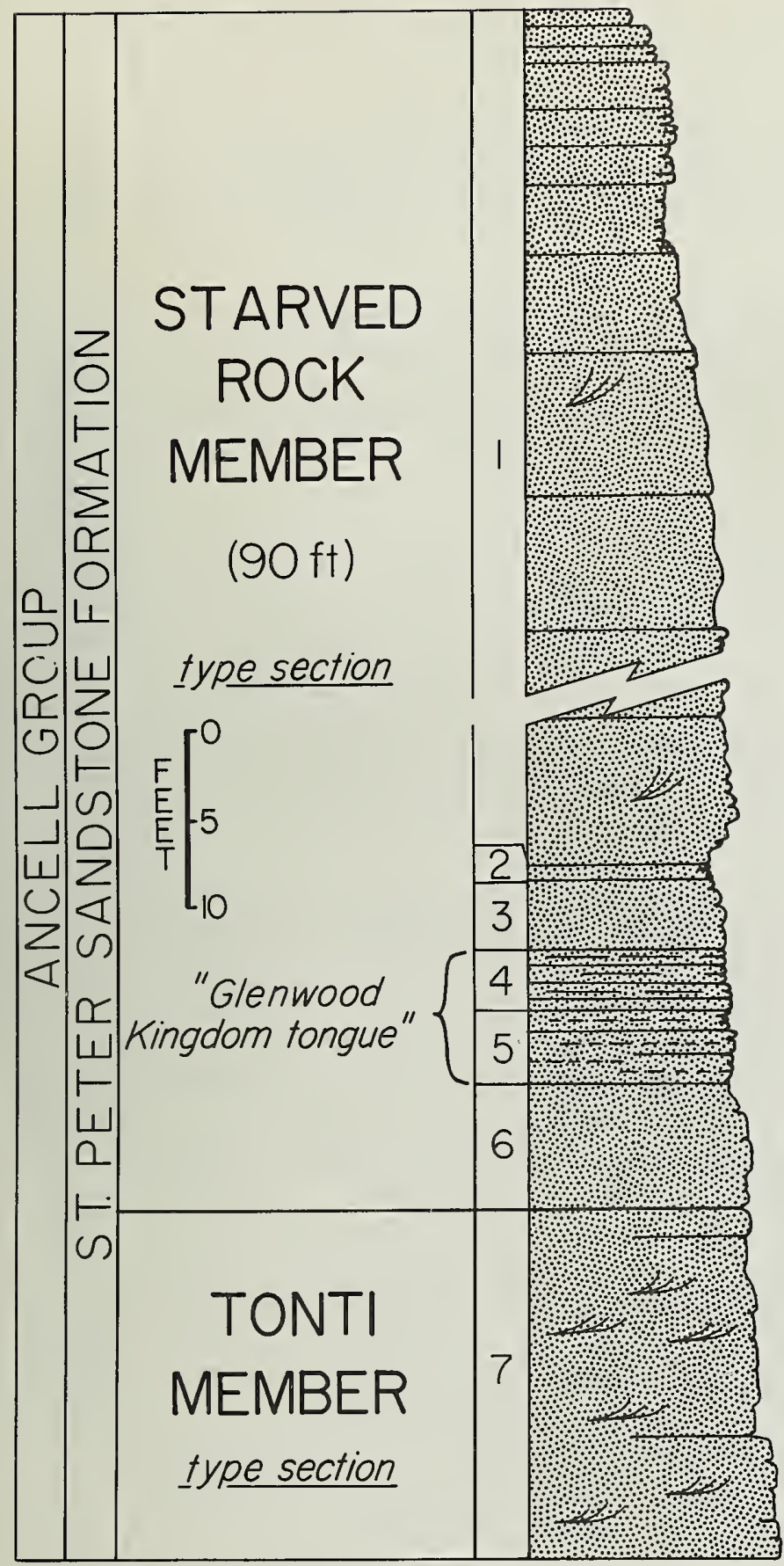

1. Sandstone - light brown to white, consists of mediumsize well rounded quartz grains, well sorted, thickbedded.

2. Sandstone - white, silty, consists of fine well rounded quartz grains, friable.

3. Sandstone - gray, consists of medium-size quartz grains, well sorted, massive.

4. Sandstone - 1ight brown to white, bimodal in texture, consisting of both fine and coarse well rounded quartz grains (Glenwood texture), argillaceous, thin-bedded.

5. Sandstone - light brown to white, consists of well rounded very fine to medium quartz grains, friable, silty streaks.

6. Sandstone - 1ight brown to white, consists of medium well rounded quartz grains, friable, well sorted.

7. Sandstone - light brown to white, consists of fine well rounded quartz grains, friable, well sorted, thickbedded, common1y cross-bedded. Base concealed below water.

Fig. 5 - Stratigraphic section at Starved Rock. Some of the Tonti Sandstone is under water at the base. This section, along with those at Lover's Leap and French Canyon to the east, represents the type sections of both the Starved Rock and Tonti Members

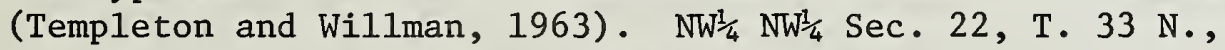
R. 2 E., La Salle County, Ottawa Quadrangle. 


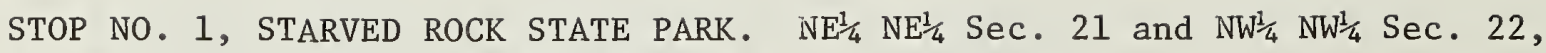
T. 33 N., R. 2 E., Ottawa Quadrangle.

The Starved Rock area became a state park in 1911 after development by a hotel company. In earlier years it had been advertised as the "Gibraltar of the West" and at one time boasted a dance floor on the summit of Starved Rock.

The history of white men in the area dates to 1673 when Louis Joliet, a French explorer, and Jacques Marquette, a Jesuit priest, stopped at a large Indian village on the north bank of the river, just above starved Rock. Two years later, Father Marquette founded a mission at the village, which persisted for many years.

In 1683, René Robert Cavalier, Sieur de La Salle, built a fort near Starved Rock and established a village that grew to number about 10,000 Indians. The fort was the westernmost of a chain of forts established by the French and was the base of operations for La Salle's extensive explorations. During the $1680^{\prime} \mathrm{s}$, it was here that Tonti of the Iron Hand organized the Illinois Indians to help New France fight the Iroquois-the fort was besieged by Iroquois for six weeks during one raid. Starved Rock is located at the lowest rapids on the Illinois, and the fort controlled passage from Canada to the southwest. In 1691, the fort was abandoned and a new one was built at Peoria.

In 1722, Illinois Indians are said to have been marooned on the top of Starved Rock by Fox Indians but were rescued by the French. Among the Potawatomis, legend has it that in ancient times a part of the Illinois tribe was besieged on the Rock, starved into submission, and then massacred. The area has been a source of abundant Indian artifacts and remains for many years. Two village sites are in the park bottomland, along with burial mounds. In addition, burials have been found in park shelter caves and, at the head of French Canyon, the remains of a Shawnee village preserved since La Salle's time persisted into recent years.

Starved Rock and the bluffs up and down river from it are composed of sandstone of the Champlainian (Middle Ordovician) St. Peter Formation. The lowermost 20 feet of the Rock (fig. 5) is formed by the Tonti Sandstone Member (Templeton and Willman, 1963), which consists of fine-grained, white to light brown, well sorted, thick-bedded, strongly cross-bedded sandstone. It is overlain by 90 feet belonging to the Starved Rock Member, which is a medium-to coarse-grained, white to light brown, thick-bedded massive sandstone that is only slightly cross-bedded. Starved Rock is the type section for both members.

In French Canyon (due south of the Rock), 10 feet of buff dolomite of the Pecatonica Formation (Platteville Group) can be seen overlying the Starved Rock Sandstone Member.

The valley of the Illinois River here is essentially a product of meltwater outflow from the various lobes of Woodfordian glaciers as well as from glacial Lake Chicago. The present deep gorge was cut mainly during two major stages of erosion. The first occurred during the retreat of the Valparaiso glacier about 14,000 years ago, when large amounts of water were discharged down the valley. The Valparaiso Morainic System lies 10 to 20 miles west and southwest of Lake Michigan and parallels the shore. In such 
a position, the ice margin contributed most of its meltwater to the valley of the Kankakee River about 40 miles southeast of here, whence it flowed into the Illinois. At the height of the flood, which was named the Kankakee Flood (Willman and Frye, 1970), waters backed up between moraines and formed several large lakes: Lake Ottawa, Lake Pontiac, Lake Wauponsee, and Lake Kankakee. As floodwaters slackened, the valley of the Illinois was cut to the level of the top of Starved Rock.

The second stage of downward cutting took place when glacial Lake Chicago, the ancestor of present-day Lake Michigan, overflowed down the valley, deepening it approximately another 60 feet in the interval from about 13,500 to 3,000 years ago. Lake Chicago resulted from the trapping of water between the Tinley Moraine on the back side of the Valparaiso Morainic System and the front of the glacier that occupied the Lake Michigan Basin. The Ottawa Terrace represents the lowest level cut by the Chicago Outlet River. A deep groove low in the cliffs of Starved Rock and Buffalo Rock marks the level of the floodwaters. Since then, the modern river has cut its inner valley another 30 feet to reach its present level.

In the upper part of several valleys in the park, the Cheltenham Clay Member of the Pennsylvanian Spoon Formation can be seen underlying the Colchester (No. 2) Coal Member.

\section{$\underline{\text { Mileage }}$}

Adjust odometer. Leave parking lot in convoy.

00.00 Turn left (south) onto road.

00.0500 .05 Left turn (east).

$00.2500 .20 \quad$ Right turn toward valley wall.

00.3500 .10 STOP SIGN. Climb steep hill.

00.7500 .40 Road on left leads to Lodge. Continue straight ahead.

01.2500 .50 STOP SIGN. Junction with Illinois Route 71 . Turn right (west) on Route 71.

02.0500 .80 Junction with Illinois Route 178. Do not stop. Continue straight ahead.

03.5501 .50 We are crossing over the crest of the La Salle Anticline. The structure, which consists of a broad, nearly monoclinal fold, has a westerly dip of about 2000 feet per mile and an easterly dip of about 25 to 50 feet per mile. Northwestward from here it trends S. $24^{\circ} \mathrm{E}$. Southwestward from here it trends $\mathrm{S} .15^{\circ} \mathrm{E}$. The anticline is the largest structural feature in northeastern Illinois and marks the northeastern limit of the Illinois Basin. 
$04.0500 .50 \quad$ Sharp right turn.

$04.3500 .30 \quad$ Sharp left turn.

05.0500 .70 Abandoned cement quarry in Pennsylvanian La Salle Limestone Member (McLeansboro) on left.

05.2500 .20 Roadcut displaying the La Salle Limestone Member of the Bond Formation on both sides of the highway.

05.35 00.10 Bridge over Vermilion River and C, B \& Q Railroad tracks that serve the Marquette Cement Manufacturing Company quarry. Cement manufacture represents the main industry in the Oglesby-Jonesville area.

05.5500 .20 Enter Jonesville. Note the red-topped conical spoil pile on the right. It represents the remains of La Salle County Carbon Coal Company Jones No. 1 Mine-opened in 1886 and closed in 1928. Three feet of Danville (No. 7) Coal were mined at a depth of 217 feet. Four feet of Herrin (No. 6) Coal were mined at 276 feet, and $3 \frac{1}{2}$ feet of Colchester (No. 2) Coal were mined at 436 feet.

$05.6500 .10 \quad Y$-intersection with Route 71 North. Bear left on 71 . The highway turns up the river bluff and sweeps to the right after the left turn.

05.9500 .30 Cross railroad bridge halfway up hill. Enter Oglesby on La Salle Street.

$06.8500 .90^{\circ}$ STOP SIGN at Walnut Street, the main thoroughfare. Turn right (west) on Walnut (Route 71 continues straight ahead).

06.9500 .10 Indiana General Manufacturing plant on left.

08.6501 .70 STOP SIGNAL. U.S. Route 51. Turn left (southeast) onto Route 51. NOTICE! After turning onto Route 51, we will travel 2.4 miles and turn left .2 mile beyond the junction of Route 51 and Route 71. BE ALERT! Be prepared to turn left just beyond the center divider in the highway. ONCOMING TRAFFIC MAY BE FAST.

$11.10 \quad 02.45 \quad$ Junction of Routes 51 and 71 .

11.3000 .20 Turn left onto a secondary blacktop road just beyond the center divider.

11.4500 .15 Turn right (east). Cross railroad track and pass twin silos on the right.

12.1000 .65 Continue straight ahead on gravel road. The blacktop road turns right. 


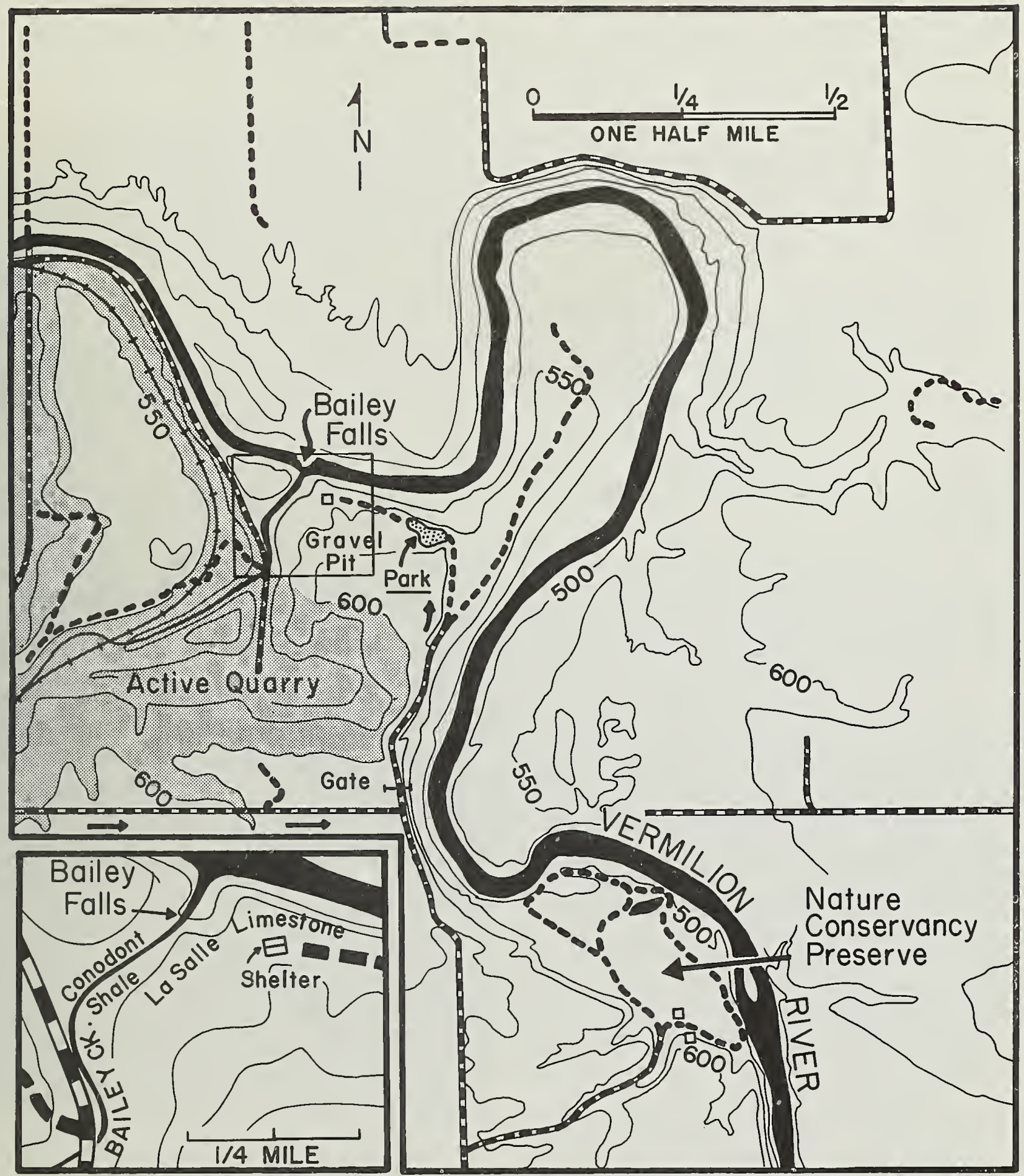

Fig. 6 - General setting of Bailey Falls. The inset map (lower left) shows the geographic location of the shale from which natural conodont assemblages may be collected. See figure 8 for location. 
12.35 00.25 View of the cement quarry on the left. Bridge over Bailey Creek.

$12.4500 .10 \quad$ Concrete bridge over railroad.

13.2500 .80 T-road. SLOW. Turn left into private road along edge of bluff of Vermilion River. On the left, the south working face of the Marquette Cement Manufacturing Company quarry can be seen. The uppermost ledge represents the Little Vermilion Limestone Member of the Pennsylvanian Bond Formation.

13.75 00.50 Turn left and park in gravel pit stockpile area. The walk to the Bailey Falls locality (fig. 6) will be approximately a quarter of a mile and, except where a gravel pit intersects the road, will be an easy hike. Returning is a different matter. If you collect heavily, please ask assistance in carrying your samples.

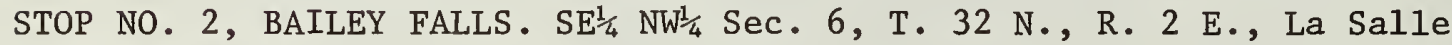
Quadrangle.

The entry road formerly continued parallel to the Vermilion River as far as Bailey Falls. It is now interrupted by a gravel pit. After crossing the pit, you will find that the road continues on the downslope side. Bailey Falls is identified by a partially ruined picnic shelter, a limestone cliff, and a jumble of large limestone blocks that have been undercut by Bailey Creek.

The cliff and jumbled blocks are DANGEROUS. PLEASE DO NOT STAND NEAR THE EDGE OR UNNECESSARILY LONG BENEATH THE CLIFF. The La Salle Member of the Bond Formation forms the cliff (figs. 8 and 9). It is underlain by black and gray shale which forms the immediate banks of Bailey Creek. At the mouth of the creek, the Hall? Limestone Member forms a low waterfall. In addition to natural assemblages (figs. 7 and 10), discrete conodonts have been found in virtually every part of the section. Merrill has collected faunas in abundance from all of the limestones as well as from one shale (table 1) and has recognized four distinct biofacies in this section. Bed 9 of figure 8 contains important Cavusgnathus (Adetognathus of Lane [1967], and other authors) and is referred to as the Cavusgnathus biofacies. The biofacies is interpreted as characteristic of nearshore environments and significant for biostratigraphic subdivision only in that it tends to dilute the short-ranging gnathodid populations in some faunas.

Beds 10, 11, and 12 (fig. 8) have yielded an Appalachian biofacies fauna. The Appalachian biofacies is dominated by Streptognathodus and is made up of species that have been used for zonation of the Conemaugh Group in Pennsylvania (Lane, Merril1, Straka, and Webster, 1971, fig. 4, p. 409). The Conemaugh zonal species Streptognathodus elegantulus, $\underline{S}$.

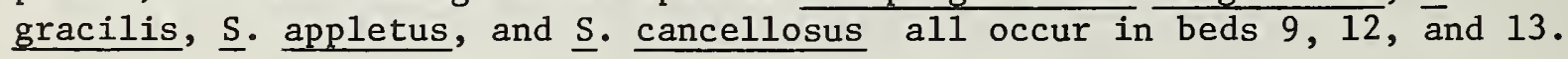

Bed 13 is of special interest in that it has an important Idiognathodus population, which is indicative of older Midcontinent faunas and is therefore referred to as representing a Midcontinent biofacies (Lane, Merrill, 
Straka and Webster, 1971, p. 406-412). In the Appalachian province, Idiognathodus is the most abundant platform in the Pottsville and Allegheny Groups but is not numerically important above the lowest part of the Conemaugh. The occurrence of the genus at Bailey Falls is near the top of its stratigraphic range.

Beds 1 and 2, which are exposed at the south end of the quarry as well as in the north bluff of the Vermilion River and in the Route 51 roadcut south of the Illinois River, contain abundant Gondolella. Because of its spotty stratigraphic occurrences, Gondolella appears to be environmentally restricted and apparently indicates a distinct biofacies. The genus is not known from Appalachian faunas.

An interesting occupation is the reconstruction of assemblages based on the species listed in table 1. Abundances range from approximately 140 specimens per kilogram up to 870 per kilogram. WHILE COLLECTING, ALWAYS BE ALERT TO OVERHANGING ROCKS ABOVE AS WELL AS TO PERSONS WHO MAY BE BELOW YOU ON THE SLOPE. PLEASE BE CAREFUL!

\section{LOCATION OF THE NATURAL ASSEMBLAGE}

\section{COLLECTING ZONE AT BAILEY FALLS}

One of the most prolific localities for collection of natural conodont assemblages, outside of Montana (Scott, 1942), and the topotype locality for Duboisella typica Rhodes and Scottognathus typicus (Rhodes) is the Bailey

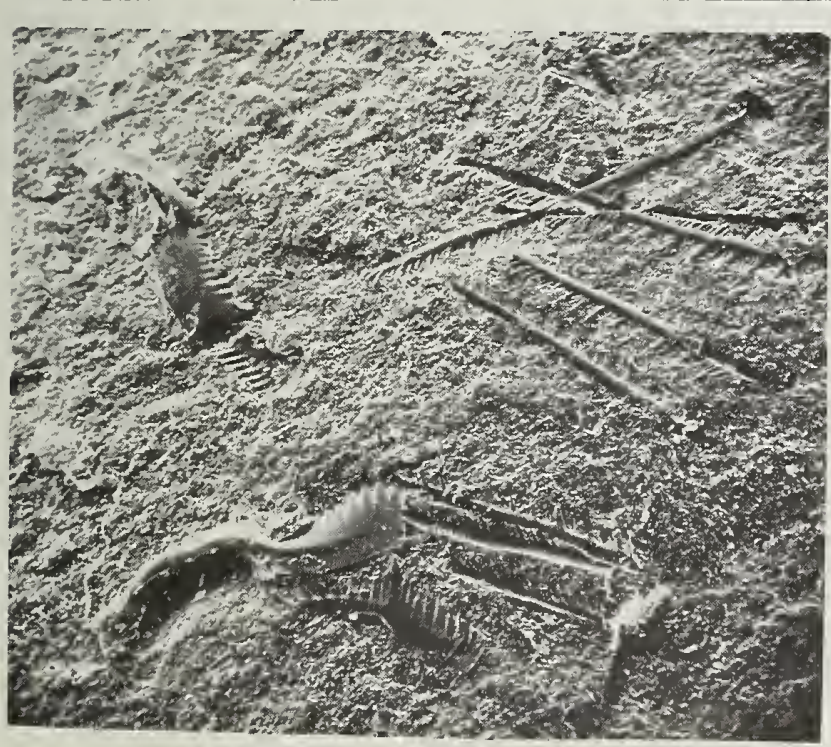

Fig. 7 - Natural assemblage of Scottognathus typicus (Rhodes) illustrating simple scatter after contraction of assemblage (X25). See also figure 10 .
Falls section. Ernest P. DuBois (1941) was the first to publish notice of the occurrence of natural assemblages here. In the same report, he recognized natural assemblages that consist of a pair of platform elements, a pair of "bryantodids," and several pairs of hindeodellids, all in a linear series. The form is Scottognathus (Rhodes) 1952 (fig. 7). DuBois also identified one speciment that exhibited three platform elements. By 1942 , DuBois had collected between 75 and 80 assemblages from a total of 300 pounds of shale. He described the stratigraphic location as "fissile black shales which lie just below the La Salle limestone of McLeansboro (Pennsylvanian) age. Underlying the black shale is a seam of coal which varies from one to several inches in thickness. The shale member is about 18 inches thick but tends to vary from one area to another." The precise stratigraphic location of the most productive zone found by Avcin and Norby is 13 to 19 inches 


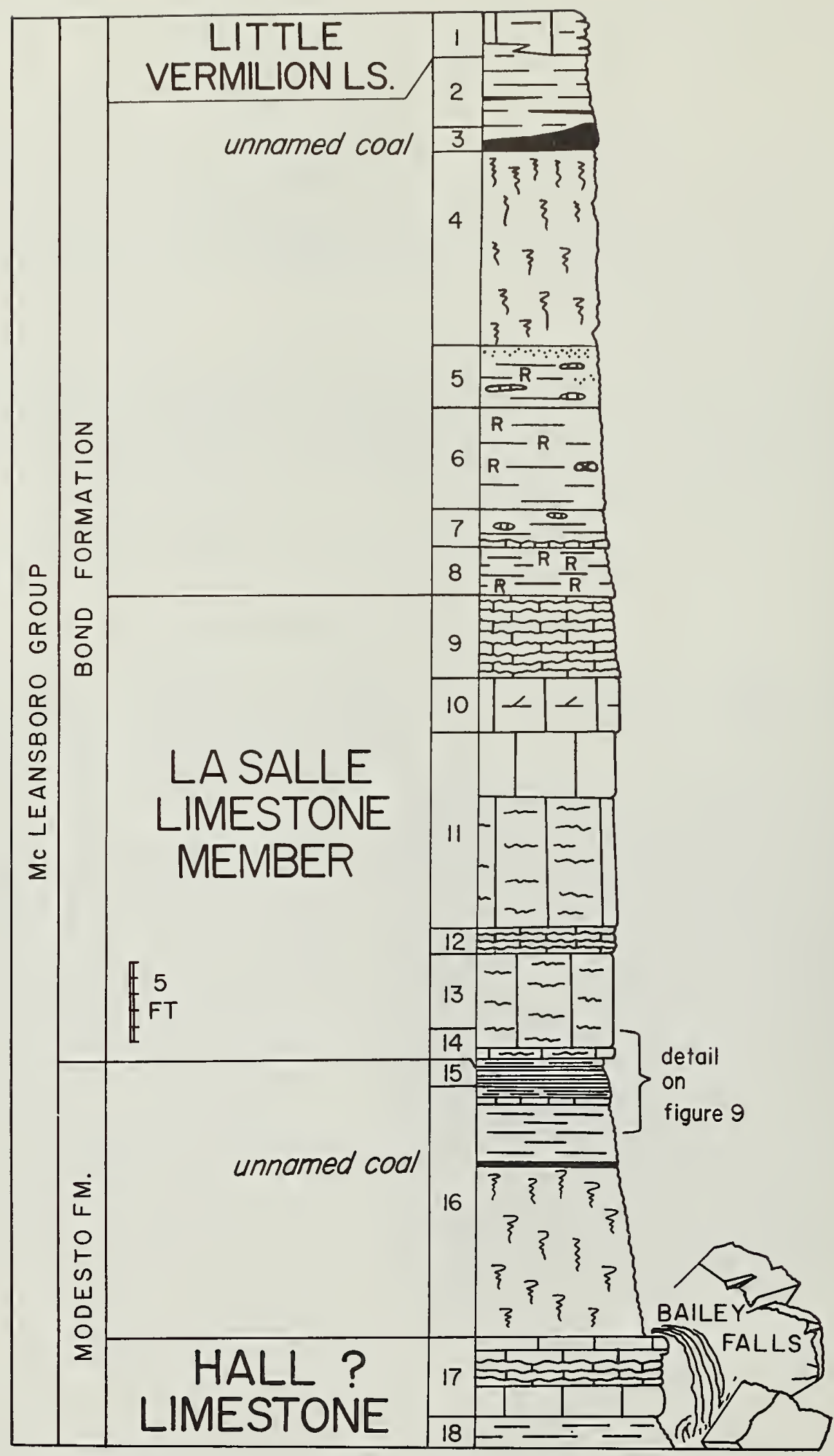

Fig. 8 - Stratigraphic section exposed at Bailey Falls (beds 9-18), SE $\frac{1}{4}$ SE $\frac{1}{4}$

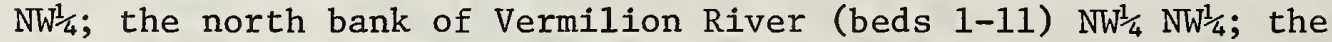
southernmost face of Marquette Cement Manufacturing Company quarry (beds 1-9) $S \frac{1}{2} \mathrm{~S} \frac{1}{2}$, all in Sec. 6, T. 32 N., R. 2 E., La Salle County, La Salle Quadrangle. See figure 9 for details of assemblage collecting. 


\section{FIGURE 8 EXPLANATION}

1. Limestone - light gray, argillaceous, shaly; very fossiliferous in places, numerous Rhipidomella carbonaria (Swallow), pelecypods, gastropods, and shark's teeth.

2. Shale - dark gray; thin coal seams.

3. Coal - soft, irregular in thickness.

4. Clay - gray to light gray, unbedded, pyritic, carbonaceous near top.

5. Shale - red and gray mottled; contains red and gray limestone concretions; gray, sandy, micaceous layers mostly near top.

6. Shale - red; contains limonite concretions.

7. Shale - greenish gray, silty; contains limestone nodules; contains some red shale layers.

8. Shale - red with greenish gray mottling.

9. Limestone - light gray to brownish gray, algal, very nodular with greenish gray interbedded clay; contains abundant brachiopods and crinoid columnals; pyrite present on upper surface.

10. Limestone - gray to brownish gray, dolomitic, massive, biocalcarenitic.

11. Limestone - brownish gray to gray, algal, massive, vuggy, nodular in places, finely brecciated.

12. Limestone - gray to greenish gray, dense to crystalline, algal, interbedded with greenish gray shale; contains gastropods, crinoid remains, and abundant brachiopods.

13. Limestone - gray to brownish and greenish gray, dense to crystalline, algal, nodular, brecciated with shrinkage cracks; brachiopods common.

14. Shale - greenish gray grading to dark gray downward, poorly laminated, calcareous; brachiopods abundant.

15. Shale - black, fissile to blocky, pyritic; contains some plant remains, as well as fish scales, linguloid and orbiculoid brachiopods, and abundant conodonts.

16. Clay - dark gray to black at top grading downward to gray in upper two feet; contains considerable plant debris; 1- to 2-inch discontinuous limestone bed 6 inches to one foot below top; 3-inch coal seam 60 inches below top.

17. Limestone - upper ledge gray to greenish gray, dense, algal, fossiliferous; middle ledges brownish gray to greenish gray, algal, nodular, interbedded with greenish gray clay; lower ledge buff to brown, dolomitic, vuggy, and crystalline.

18. Shale - greenish gray. 


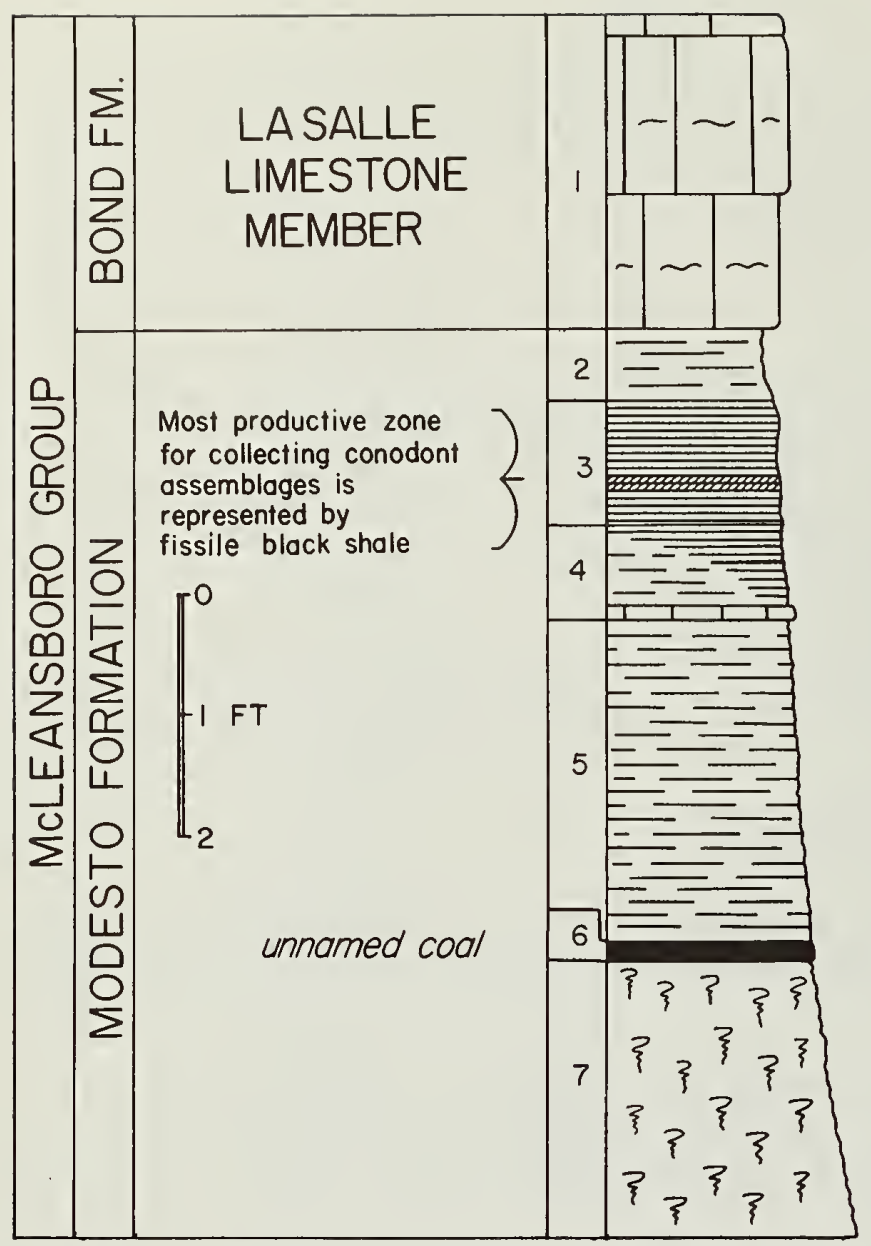

Fig. 9 - Detailed stratigraphic diagram of the beds underlying the La Salle Limestone 5 . which yield natural conodont assemblages. The most productive collecting zone (diagonal hatching) extend's from the falls upstream past

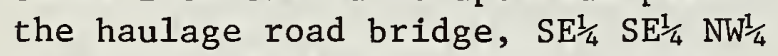
Sec. 6, La Salle County, La Salle Quadrangle. See table 1 for additional information on conodont occurrences.
1. Limestone - gray to greenish gray, dense to crystalline; contains small-scale algal structures; brecciated; brachiopods common.

2. Shale - greenish gray at top grading downward to dark gray and black, calcareous; weathers light; poorly laminated; 5 to 7 inches in thickness.

3. Shale - black, weathers dark gray on surface; blocky, pyritic; contains scattered plant remains, as well as linguloid and orbiculoid brachiopods and fish scales. Productive zone of well preserved conodont assemblages is 2 to $2 \frac{1}{2}$ inches above the base of unit and is about 1 inch thick. Thin layers of gypsum occur at the base of the zone in places, above it in other places.

4. Shale - black to dark gray at top grading downward to gray; plant debris and thin coals are common; 1 - to 2-inch discontinuous limestone bed at bottom.

5. Shale - gray to light gray; plant debris common.

6. Coa1 - 1 to 3 inches thick.

7. Clay - gray to light gray. 
TABLE 1 - Numbers of individual conodont elements tentatively identified by Glen K. Merrill from samples collected at Bailey Falls. Bed number refers to bed numbers given in figure 8. Weight refers to the weight of the individual sample from which the specimens were collected. The numbers in parentheses in the Species column are for identification of unnamed taxa.

\begin{tabular}{|c|c|c|c|c|c|c|c|}
\hline \multirow{3}{*}{ Species } & & & \multicolumn{3}{|c|}{ Bed Number } & \multirow[b]{2}{*}{17} & \multirow[b]{2}{*}{ Total } \\
\hline & 9 & $10 \& 11$ & 12 & 13 & 14 & & \\
\hline & & & \multicolumn{3}{|c|}{ Weight (grams) } & & \\
\hline & 2173 & 1640 & 1251 & 1444 & 2068 & 2978 & \\
\hline
\end{tabular}

Streptognathodus

elegantulus Stauffer \& Plummer

S. gracilis S. \& P.

S. excelsus S. \& P.

S. cancellosus (Gunne11)

S. appletus Ellison

S. spp.

Idiognathodus delicatus Gunnel1

Cavusgnathus lautus Gunne11

C. gigantus Gunnell

SFathognathodus minutus (E11ison)

ozarkodina delicatula (S. \& P.)

O. n. sp. (3)

O. n. sp. (4)

o. spp.

Ligonodina lexingtonensis (Gunne11)

I. typa (Gunnel1)

L. n. sp. (4)

I. n. $\mathrm{sp} \cdot$ (10)

New genus, $\mathrm{n}$. sp. (1)

New genus, n. sp. (3)

Hindeodus $\mathfrak{n}$. $\mathrm{sp}$. (1)

H. n. sp. (2)

$H . \mathrm{n} \cdot \mathrm{sp} \cdot(3)$

H. n. sp. (4)

$H$. spp.

Hibbardella subacoda (Gunne11)

H. n. sp. (1)

H. n. sp. (2)

H. n. sp. (3)

Neoprioniodus conjunctus (Gunne11)

N. n. sp. (6)

N. n. sp. (7)

N. n. sp. (10)

Synprioniodina microdenta E1lison

$\begin{array}{lllllll}50 & 2 & 6 & 76 & 27 & 19 & 180\end{array}$

$\begin{array}{lllllll}26 & -- & 1 & 13 & 9 & -- & 49\end{array}$

$\begin{array}{lllllll}15 & 1 & 2 & 8 & 19 & 1 & 46\end{array}$

$\begin{array}{lllllll}3 & -- & 1 & 1 & 21 & 1 & 27\end{array}$

$\begin{array}{lllllll}7 & -- & 4 & 10 & 42 & 1 & 64\end{array}$

$\begin{array}{lllllll}23 & -- & 1 & 26 & 89 & 1 & 140\end{array}$

$\begin{array}{lllllll}-- & -- & -- & 14 & -- & -- & 14\end{array}$

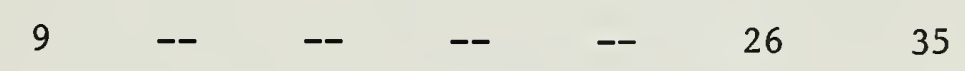

$\begin{array}{lllllll}5 & -- & -- & -- & -- & 17 & 22\end{array}$

$\begin{array}{lllllll}21 & -- & -- & 14 & 5 & 13 & 53\end{array}$

$\begin{array}{rrrrrrr}1 & -- & -- & -- & -- & -- & 1 \\ -- & -- & -- & 2 & -- & -- & 2 \\ -- & -- & -- & -- & -- & 3 & 3 \\ 7 & 1 & 2 & 38 & 10 & 10 & 68 \\ -- & -- & -- & 3 & 8 & -- & 11\end{array}$

$\begin{array}{lllllll}-- & -- & -- & 3 & 2 & -- & 5\end{array}$

$\begin{array}{lllllll}-- & -- & -- & 3 & -- & 6 & 9\end{array}$

$\begin{array}{lllllll}2 & -- & -- & -- & -- & 3 & 5\end{array}$

$\begin{array}{rrrrrrr}1 & -- & -- & 1 & -- & 2 & 4 \\ 5 & 1 & 1 & 3 & -- & 2 & 12\end{array}$

$\begin{array}{rrrrrrr}1 & -- & -- & -- & -- & -- & 12\end{array}$

$\begin{array}{lllllll}1 & -- & -- & 2 & -- & -- & 3\end{array}$

$\begin{array}{lllllll}-- & 1 & -- & -- & -- & 3 & 4\end{array}$

$\begin{array}{lllllll}1 & -- & -- & 1 & -- & -- & 2\end{array}$

$\begin{array}{rrrrrrr}-- & -- & -- & 1 & -- & -- & 1\end{array}$

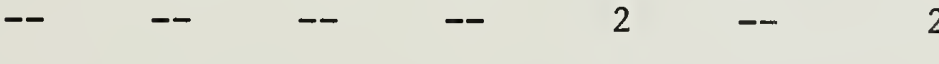

$\begin{array}{lllllll}-- & -- & -- & -- & -- & 1 & 1\end{array}$

$\begin{array}{lllllll}-- & -- & -- & 1 & -- & 2 & 3\end{array}$

$\begin{array}{lllllll}3 & -- & -- & - & -- & -- & 3\end{array}$

$\begin{array}{rrrrrrr}-- & -- & -- & 1 & 1 & -- & 2 \\ -- & -- & -- & 2 & -- & -- & 2 \\ -- & -- & -- & 2 & -- & -- & 2 \\ 3 & -- & -- & -- & -- & 1 & 4 \\ -- & -- & -- & -- & 1 & -- & 1\end{array}$ 
TABLE 1 (Continued)

\begin{tabular}{|c|c|c|c|c|c|c|c|}
\hline \multirow[t]{3}{*}{ Species } & 9 & $10 \& 11$ & \multicolumn{3}{|c|}{ Bed Number } & 17 & Total \\
\hline & & & \multicolumn{3}{|c|}{ Weight (grams) } & & \\
\hline & 2173 & 1640 & 1251 & 1444 & 2068 & 2978 & \\
\hline S. n. sp. (3) & -- & -- & -- & 3 & - & -- & 3 \\
\hline Lonchodina clarki (Gunnel1) & -- & -- & -- & 2 & 1 & -- & 3 \\
\hline L. ponderosa (Gunne11) & 1 & -- & -- & -- & 5 & -- & 6 \\
\hline Hindeodella parva Ellison & -- & -- & -- & 2 & -- & -- & 2 \\
\hline H. cf. pulchra Ellison & -- & -- & -- & 1 & -- & -- & 1 \\
\hline H. n. $\mathrm{sp} \cdot(1)$ & -- & -- & -- & 4 & -- & -- & 4 \\
\hline H. n. $\mathrm{sp} \cdot(2)$ & 1 & -- & -- & 6 & 1 & -- & 8 \\
\hline H. n. sp. (4) & -- & -- & -- & -- & -- & 4 & 4 \\
\hline H. spp. & 10 & 1 & 2 & 65 & 9 & 20 & 107 \\
\hline $\begin{array}{l}\text { Genus and species } \\
\text { undetermined }\end{array}$ & 8 & 1 & -- & 32 & 21 & 21 & 83 \\
\hline
\end{tabular}

Totals

204

$8 \quad 20 \quad 341$

$273 \quad 157 \quad 1,003$ 

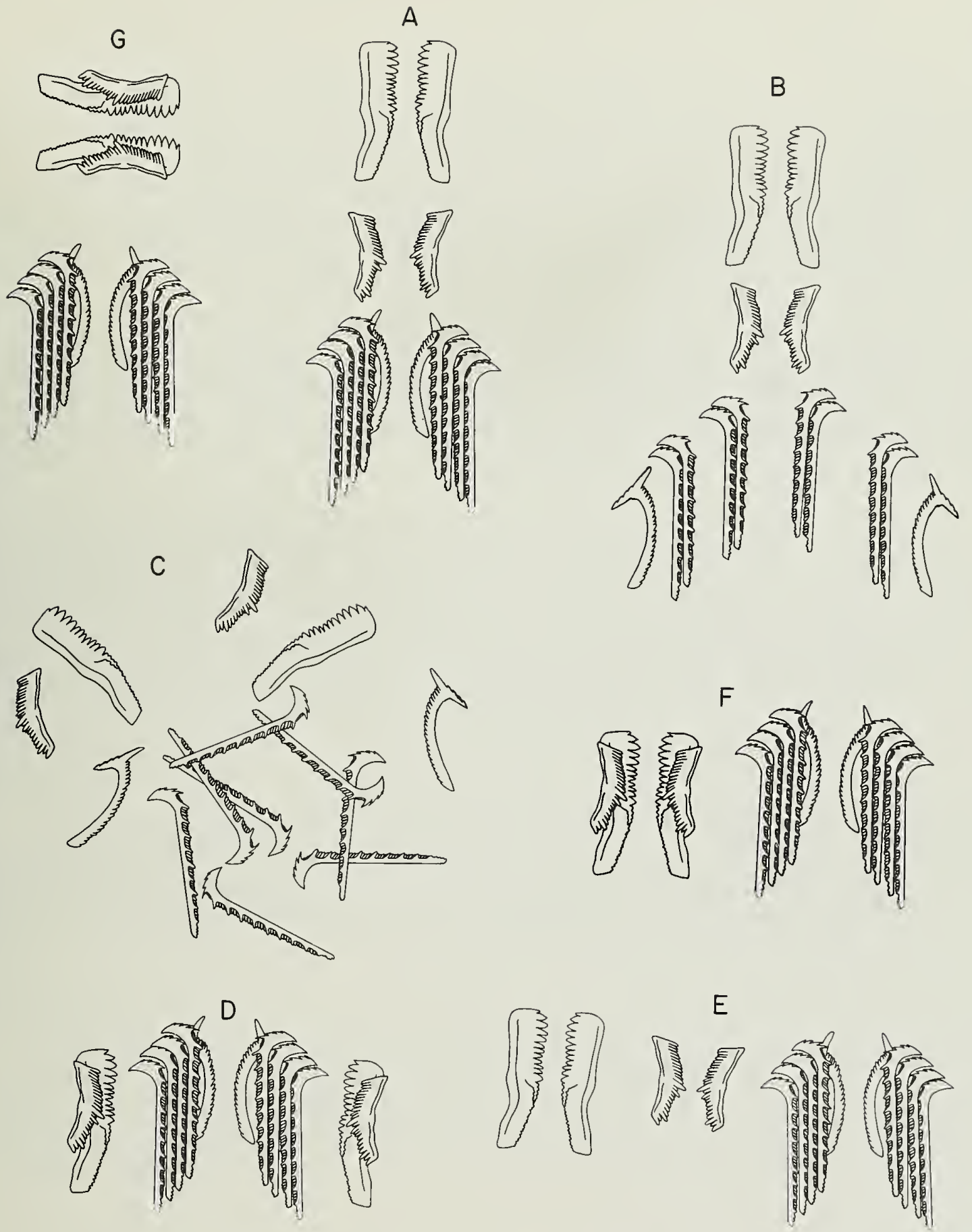

Fig. 10 - Common arrangements of natural assemblages representing Scottognathus: A, Scottognathus typicus (Rhodes) after Rhodes, 1952, text-fig. 2 , p. 891; B, rearrangement of Scottognathus typicus in light of new collections from Bailey Falls; C, example of simple scatter arrangement; $D$, example of simple contraction arrangement; E, example of simple rotation arrangement; $F$ and $G$, examples of arrangements resulting from combinations of contraction and rotation (all approximately $\mathrm{X}$ 16.6). 
below the base of the La Salle Limestone. The zone is $3 / 4$ to 1 inch thick and consists of olive gray to black shale having fine incipient planes of fissility that are virtually invisible while the shale is moist but become apparent when it is dry. The zone yields approximately one natural assemblage for every ten pounds of shale when the shale is split along planes of fissility. A sharp knife is the most effective instrument for splitting. Pieces of shale that have slumped to creek level tend to be dry and thus split more easily than fresh pieces. The zone of abundance is overlain and underlain by blocky black shale. Dunbarella is common in a thin zone directly below the assemblage collecting zone. The zone can be traced along the bank of Bailey Creek at least as far as the haulage road bridge and probably much more widely.

Amber and translucent fish scales, which occur in the black shales, may glint like conodonts and be mistaken for them when examined without magnification. Probably the most effective method of collecting is to accumulate a pile of several pounds of shale and then carefully split the slabs with a knife, examining each with a magnifying glass or hand lens. Microscopes are available at the picnic shelter. 
The natural assemblage genus Scottognathus was described by F. H. T. Rhodes (1952) from material that he collected from this outcrop and from earlier collections by E. P. DuBois (1941, 1943). The genus was diagnosed as "consisting of paired conodonts of the 'form genera' Idiognathodus or Streptognathodus, Ozarkodina, Hindeodella, and Synprioniodina" (Rhodes, 1952, p. 890) in a 2:2:8:2 ratio. The original figures (Rhodes, 1952, plate 126, fig. 11, text-fig. 2, p. 891) illustrate a linear, bilaterally symmetrical arrangement of the component elements (fig. 10A), which holds up remarkably well in light of new data from our recent collections. In fact, Rhodes' model requires only two revisions to be compatible with the new observations: (1) Present data ( $\mathrm{fig}$. 10B) indicate that the hindeodellid elements occur as lateral pairs with two pairs on either side of the assemblage. (2) Synprioniodinid elements occur farther from the mid-line of the assemblage than shown by Rhodes.

Despite the foregoing observations, an examination of collections from Bailey Falls shows that preservation of linear arrangements is relatively rare but that several patterns of element arrangement reoccur repeatedly and, by reason of this repetition, are of importance for reconstructing the details of discrete element arrangement in the conodont-bearing animal. We have categorized the patterns as: (1) simple scatter (fig. 10C); (2) simple contraction (fig. 10D); (3) simple rotation (fig. 10E); and (4) contraction-rotation combinations (figs. $10 \mathrm{~F}$ and $10 \mathrm{G}$ ).

\section{Simple Scatter}

Simple scattering of the elements is generally the result of watercurrent action and of compaction effects. Both tend to destroy the biological arrangement of the elements during and after decomposition of the animal. If scatter is not great, the assemblage is relatively easy to restore.

\section{Simple Contraction}

Contraction results from an uncomplicated anterior translation of elements relative to each other ("anterior" as used here relates to the nomenclature of discrete elements). In extreme cases, translation results in juxtaposition of hindeodellid-synprioniodinid and ozarkodinid elements to platform elements.

\section{Simple Rotation}

Rotation, as encountered here, is parallel to bedding and is the result of a 90-degree rotation of elements with respect to their original alignment. The platforms, the ozarkodinids, and the hindeodellid-synprioniodinid elements generally have been moved as independent units. Such rotation results in arrangements wherein components are oriented in the same general direction. 


\section{Contraction-Rotation Contractions}

Figures $10 \mathrm{~F}$ and $10 \mathrm{G}$ represent two arrangements resulting from interaction of contraction and rotation. In figure 10G, the ozarkodinids have been moved anteriorly to the position of the platform elements (contraction) and the combination has been rotated 90 degrees with respect to the hindeodellid-synprioniodinid units. In figure 10F, the ozarkodinids have been translated anteriorly and the resulting platform-ozarkodinid combination, as well as the hindeodellid-synprioniodinid unit, has been rotated 90 degrees.

Examination of the various patterns and their intergradations has led us to make some speculations concerning the organization and musculature of the animal that bore the natural assemblage Scottognathus.

(1) The platform, ozarkodinid, and hindeodellid-synprioniodinid units appear to have been separate biological units, individually bound by connective tissue such as muscle or cartilage.

(2) The hindeodellid-synprioniodinid units consisted of six subunits, four lateral pairs of Hindeodella and two lateral Synprioniodina individuals. The synprioniodinids were the least tightly held and generally occur farthest from the midline of symmetry.

(3) Ozarkodinids, although clearly representing a separate unit, tend to be associated with the platform unit whereas the hindeodellid-synprioniodinid unit rarely is.

Possible Causes of Post-Mortem Arrangement of Assemblages

Movement by water provides the most obvious explanation for postmortem movement and rearrangement of natural assemblages. However, in the Bailey Falls collection the fine-grained lithology of the black shale, the absence of sedimentary structures indicative of current action, and the common association of light and heavy, big and small elements tend to discount any significant work by currents. The common occurrence of orderly patterns, on the other hand, can in most cases be explained by muscle relaxation-contraction effects or by compression-decomposition effects that translated elements after death from their life position down to the surface of the sea floor on which the animal lies.

Assemblages from Bailey Falls

In addition to being the type locality for Scottognathus, Bailey Falls is also the outcrop from which the holotype of Duboisella Rhodes, 1952 was obtained. Duboisella is rare here, however. Rhodes reported it as representing only two of the approximately eighty assemblages collected from the locality, and this rarity is consistent with our data as well.

In view of present progress, the most significant natural assemblages found at Bailey Falls are those specimens that contain more than one pair of platforms per natural grouping. Forms with three or four platforms are in our collections, and although not proved to be natural groupings, they have 
been found in sufficient numbers to indicate that they may represent true and as yet undescribed genera and/or species and/or subspecies. Care must be taken, but such assemblages can generally be differentiated from fecal material and other kinds of natural clusters such as the association of multiple assemblages.

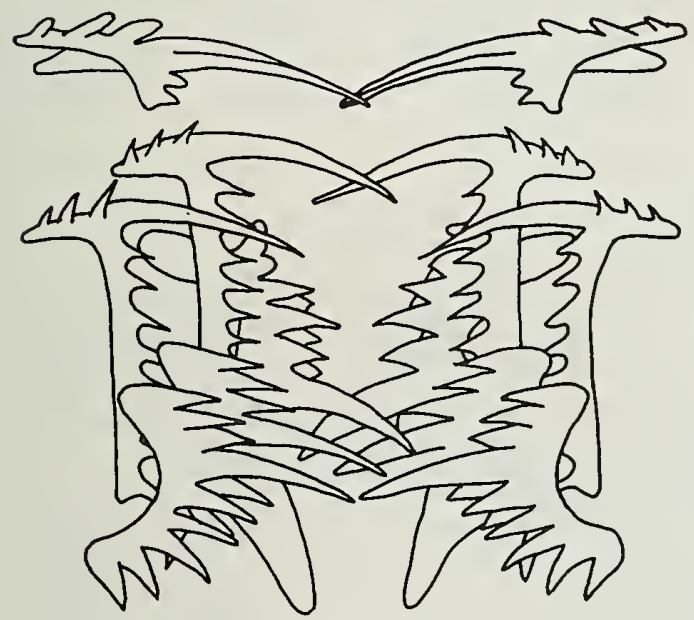

DUBOISELLA
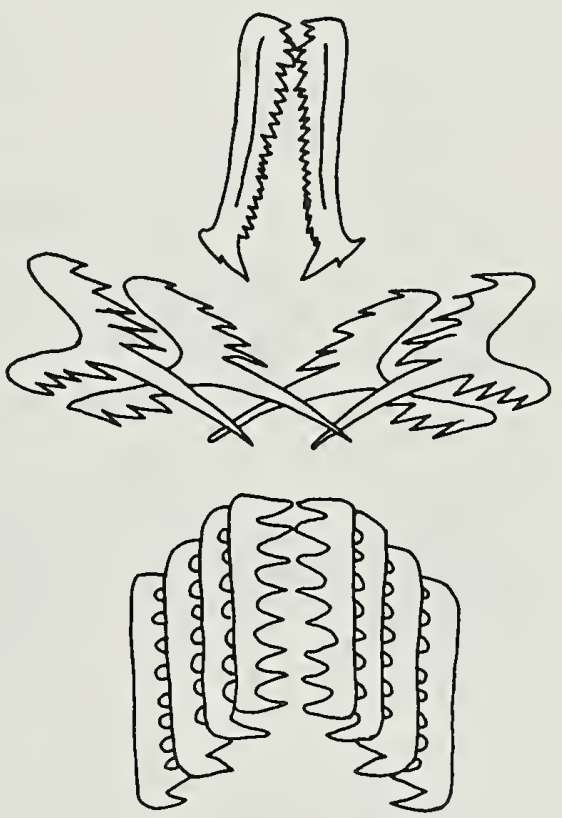

ILLINELLA 
MACRO-FAUNA OF THE LA SALLE LLLESTONE MEMBER OF THE BOND FORMATION

For those who are also interested in macro-invertebrates, the La Salle produces a fairly large fauna at this place. Below is a list of species described from the area. Plates 1 and 2 illustrate most of them.

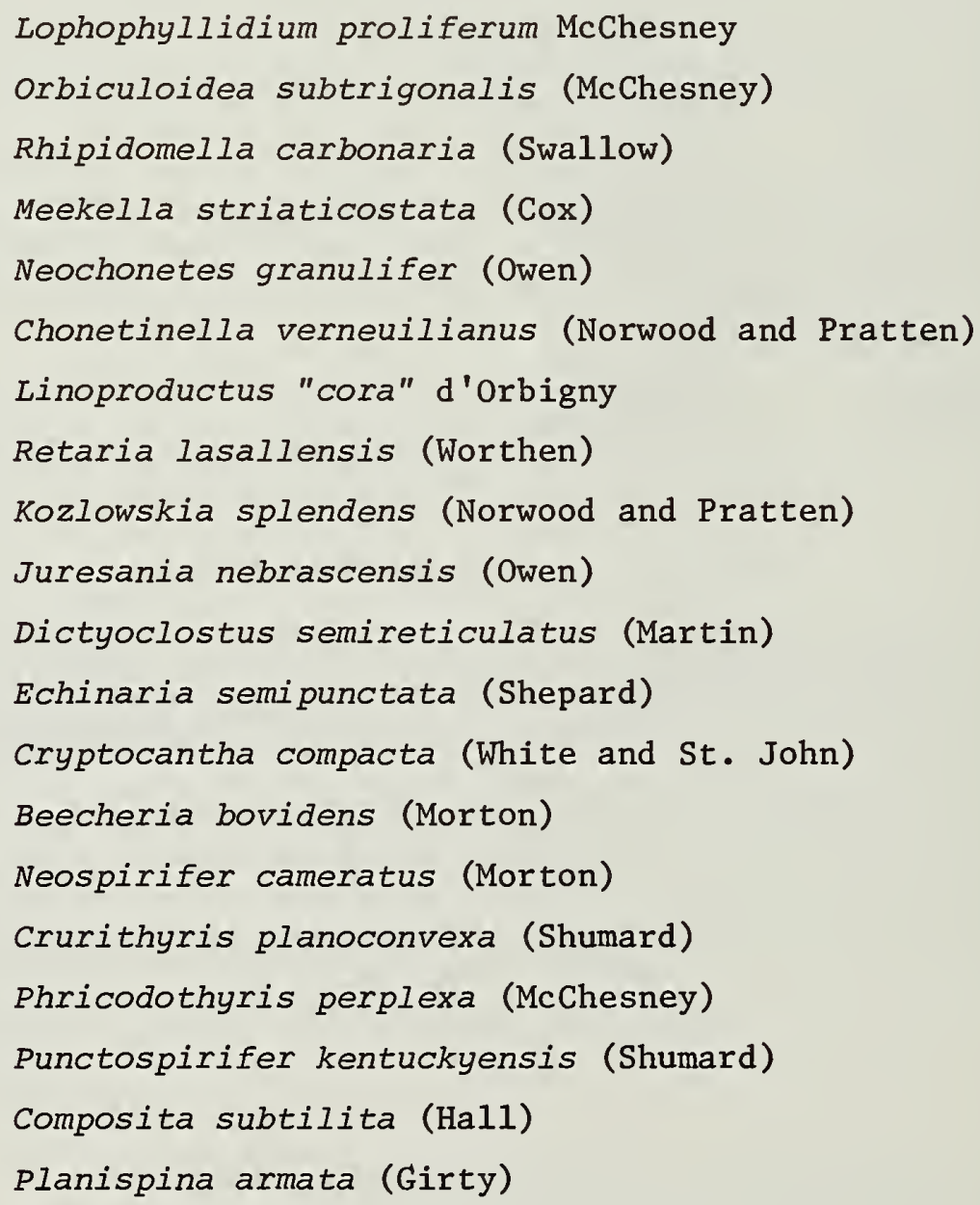




\section{COMMON PENNSYLVANIAN FOSSILS}

\section{CEPHALOPODS}

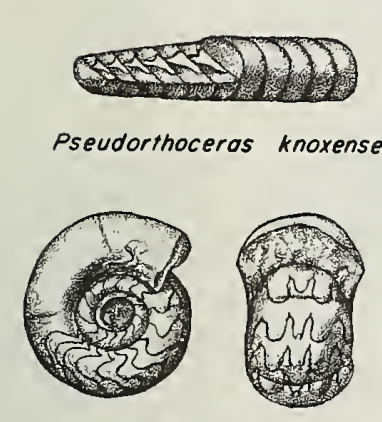

Glophrites welleri

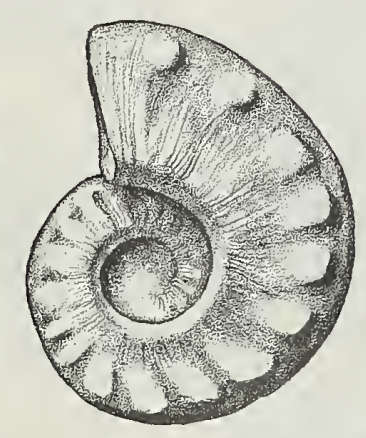

Metococeras

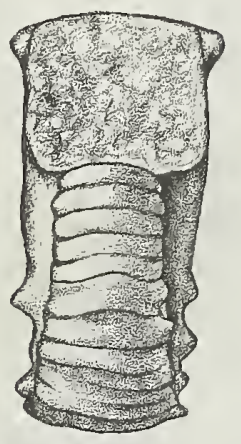

cornutum
VERTEBRATES
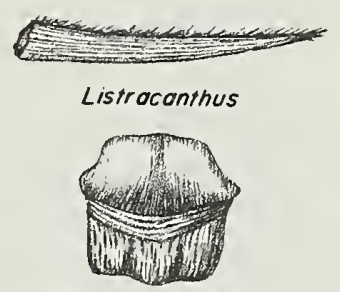

Petalodus curtus<smiles>O[As]1C=CC=C1</smiles>

Clododus deflexus

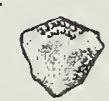

Petrodus

\section{BRACHIOPODS}
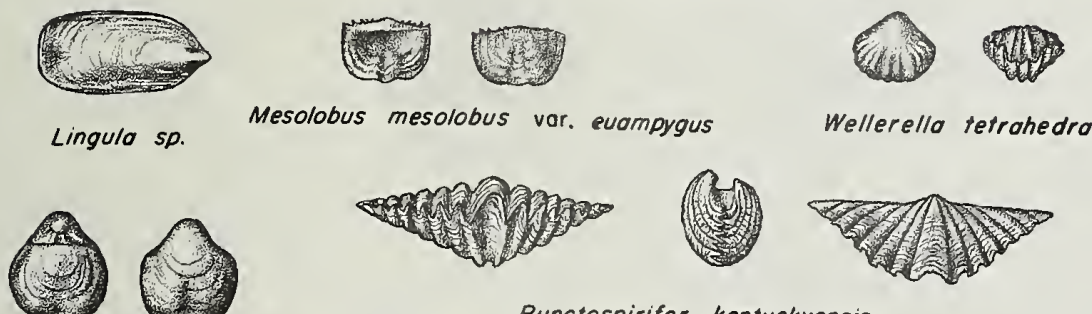

\section{Punctospirifer kentuckyensis}

Crurithyis plonoconvexo
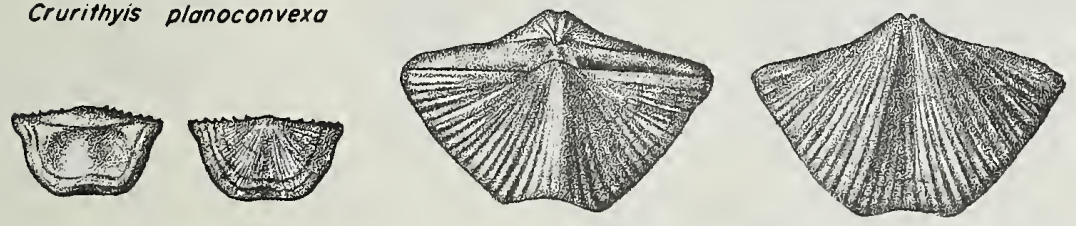

Chonetes gronulifer

Neospirifer cameratus

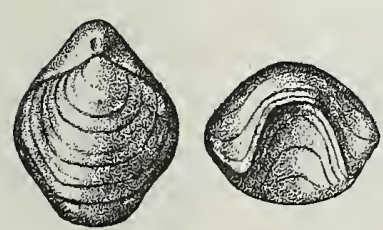

Composito orgentio
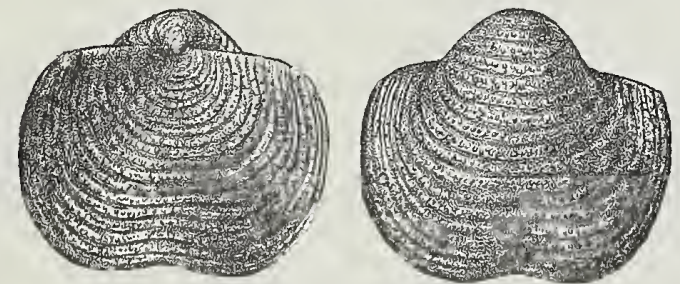

Echinoconchus semipunctotus vor, knighti
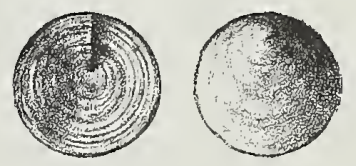

Orbiculoidea missouriensis
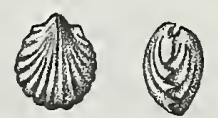

Hustedio mormoni
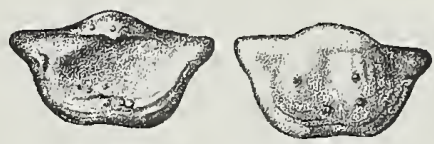

Marginifera splendens
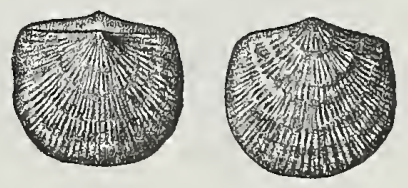

Derbyo crasso
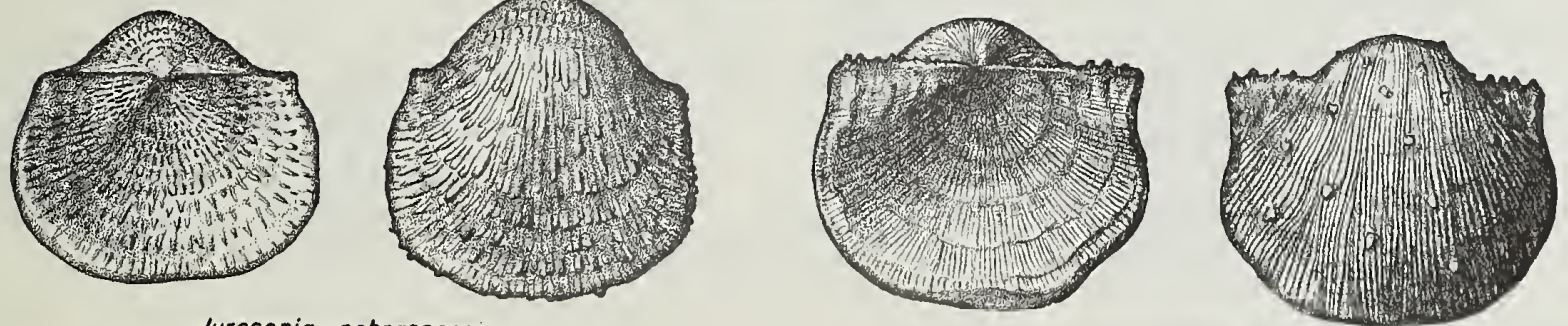

Juresonia nebrascensis

Linoproductus "coro" 


\section{CRINOIDS FUSILINIDS \\ CORALS \\ TRILOBITES}
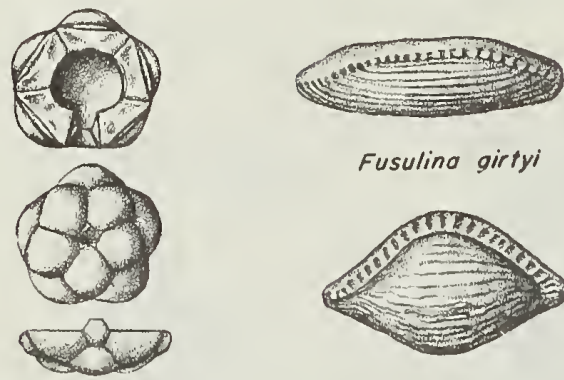

Delacrinus

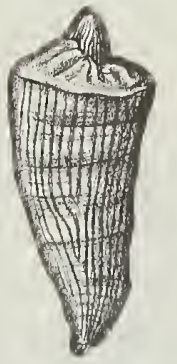

Laphaphyillidium praliferum
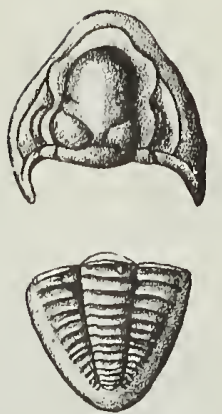
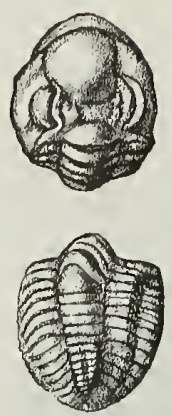

Ditomopyge porvulus

\section{PELECYPODS}
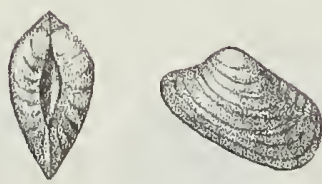

Cardiamarpho missouriensis "Type B"
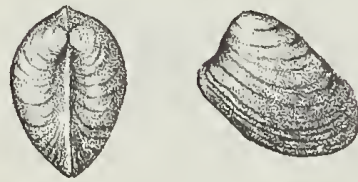

Nucula (Nuculopsis) girtyi

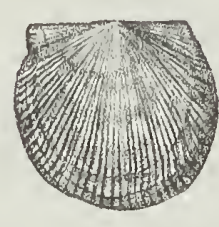

Dunbarello knighti

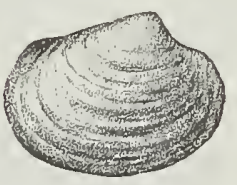

Edmonia ovata

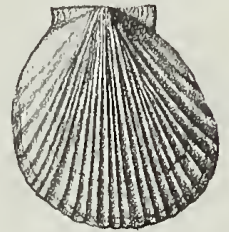

Lima retifero

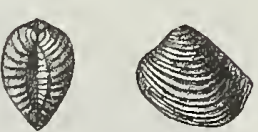

Astartella cancentrica

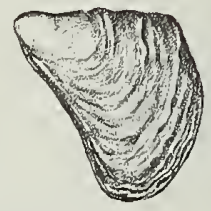

Myalina wyamingensis

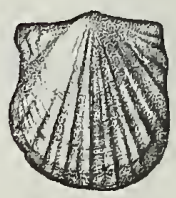

Aviculopecten germanus

\section{GASTROPODS}
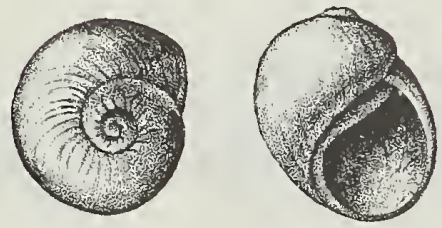

Noticopsis (Jedria) ventricoso
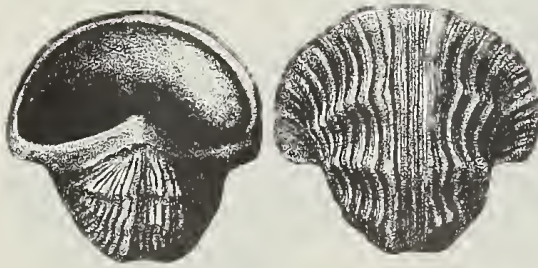

Knightites montfortionus
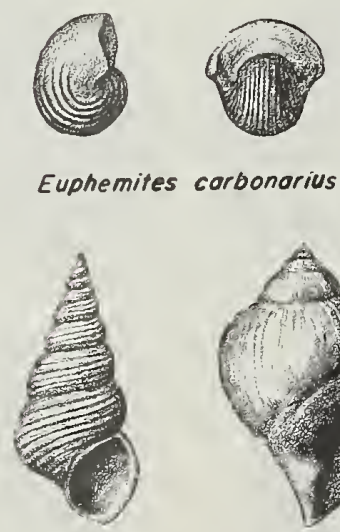

Donaldina robusta

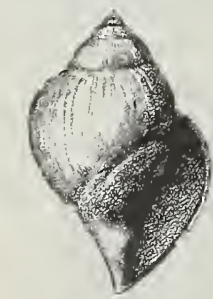

Sphoeradoma medialis

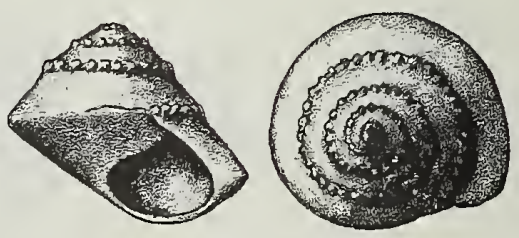

Trepospira sphaerulato
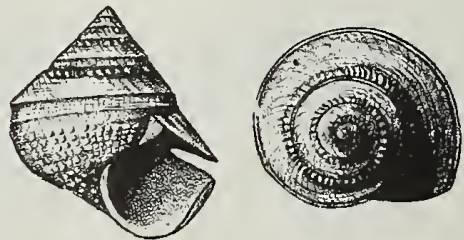

Glabrocingulum (Globrocingulum) grayvillense 


\section{OPTIONAL CONODONT COLLECTING LOCALITIES}
A. Rhodes' (1952) Locality 2.
B. Kickapoo Creek
C. Spring Valley West
D. Wolf Covered Bridge
E. La Salle East
F. Rhodes' (1952) Locality 7 .

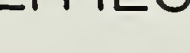



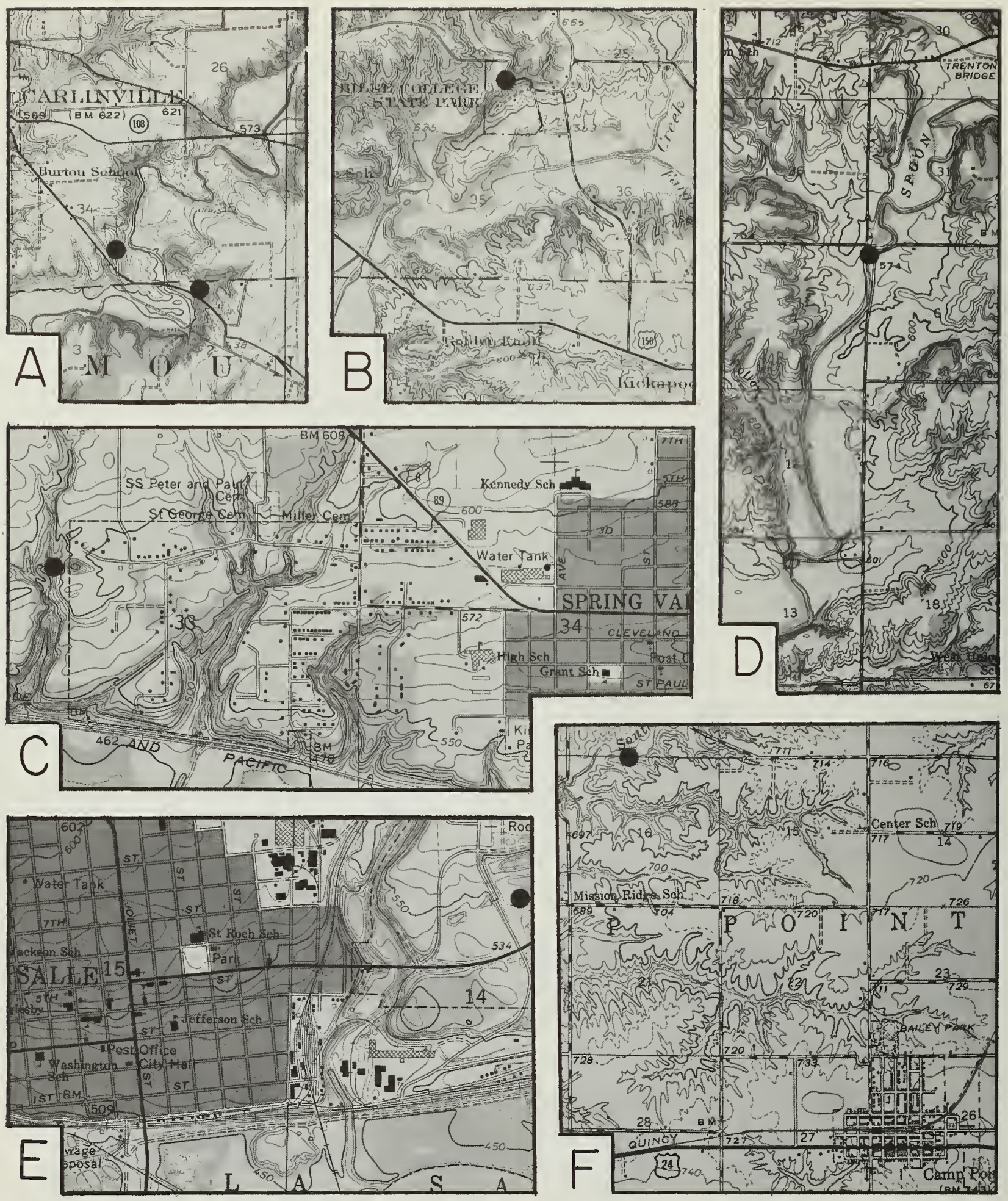

Fig. 12 - Location maps for optional stops. A, Rhodes' (1952) Locality 2; B, Kickapoo Creek; C, Spring Valley West; D, Wolf Covered Bridge; E, La Salle East; F, Rhodes' (1952) Locality 7; A, B,D, and F are $1 / 62,500$ in scale; $C$ and $E$ are $1 / 24,000$ in scale. All are taken from U.S. Geological Survey quadrangle maps. marks the approximate location of the collecting locality. (Maps are slightly reduced.) 


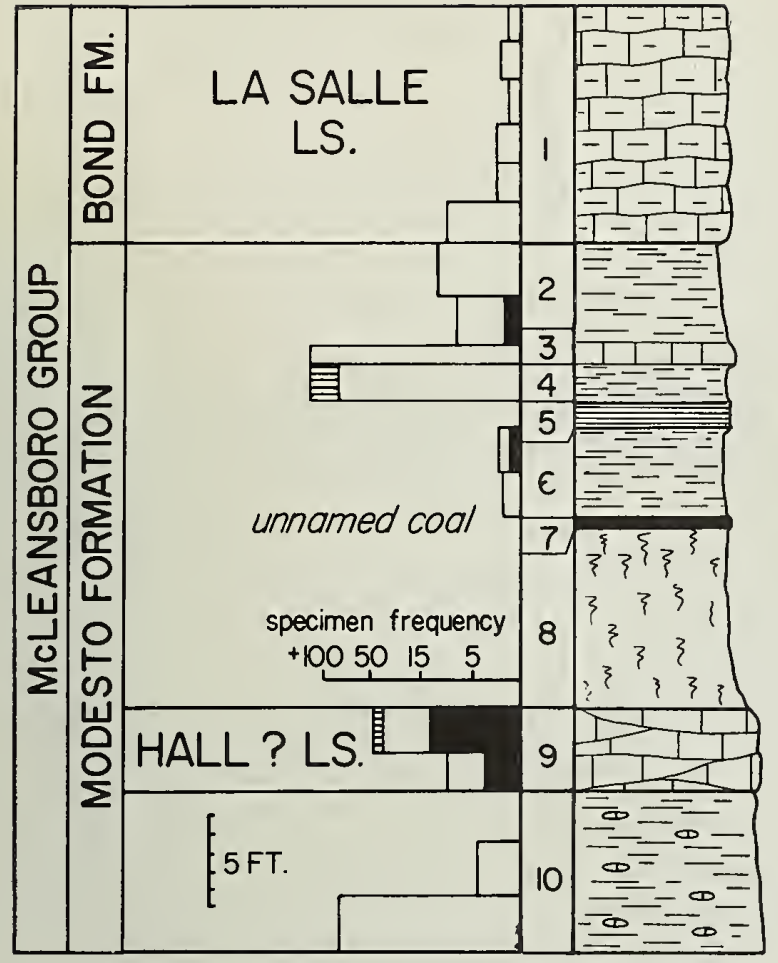

1. Limestone - light gray to brownish and greenish gray, dense, algal, nodular in places; brachiopods abundant.

2. Shale - light greenish gray to dark gray, blocky.

3. Limestone - light gray to gray, crinoidal; contains abundant brachiopods.

4. Shale - very dark gray to black, soft.

5. Shale - black to dark gray, fissile.

6. Shale - black to dark gray.

7. Coal

8. Clay - dark gray, grades downward to light gray; carbonaceous impressions in upper part.

9. Limestone - gray to light greenish gray, dense, slabby, fossiliferous.

10. Shale - light greenish gray, blocky; contains numerous limestone nodules.

Fig. 13 - SPRING VALLEY WEST, ravine west of mine dump about $1 / 2$ mile west of

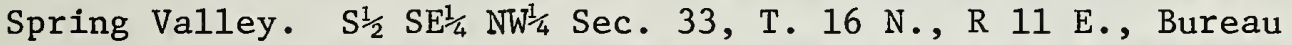
County, Spring Valley Quadrangle. The histogram indicates the number of conodonts found per kilogram of sample; the bars are divided to show ratios between the genera Gondolella (line pattern), Streptognathodus (white), and Cavusgnathus (black). 
1. Limestone - gray, shaly, fossiliferous.

2. Shale - dark gray to gray, calcareous.

3. Siltstone - gray to brownish gray, non-fossiliferous.

4. Shale - greenish gray, poorly exposed.

5. Shale - greenish gray, calcareous, fossiliferous.

6. Limestone - light gray, argillaceous, massive, very fossiliferous; contains abundant brachiopods as well as pelecypods, gastropods, and sharks' teeth.

7. Shale - dark gray to black, soft; 4 inches of irregular soft coal at bottom.

8. Clay - gray to very dark gray, calcareous, blocky; uppermost 6 inches contains carbonaceous impressions, is noncalcareous, and is laminated.

9. Shale - red, laminated, sandy, micaceous.

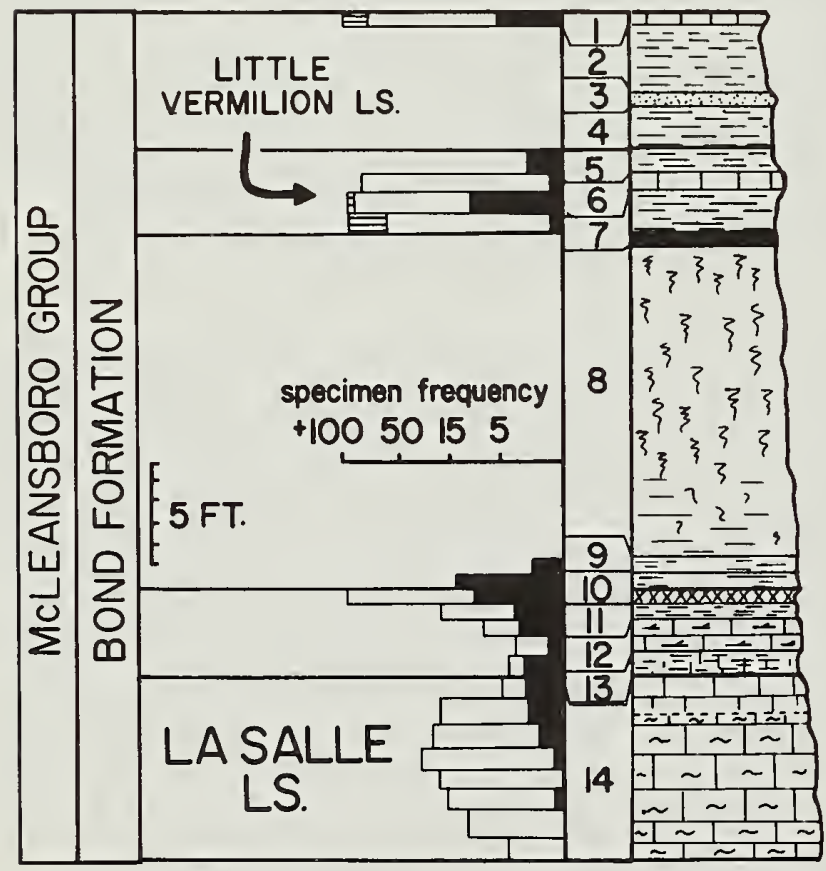

10. Shale - greenish gray, sandy, micaceous; the lowermost 6 inches consists of red and gray limestone concretions.

11. Shale - greenish gray, calcareous, and gritty.

12. Limestone - brownish gray, dolomitic, massive, dense, micritic, fossiliferous.

13. Shale - gray, calcareous; contains abundant nodules of fossiliferous limestone.

14. Limestone - gray, crystalline, algal, crinoidal, fossiliferous; contains brachiopods and gastropods.

Fig. 14 - LA SALLE EAST, section in abandoned quarry, north of U.S. Route 6,

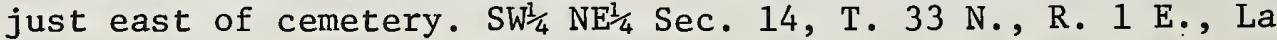
Salle County, La Salle Quadrangle. The histogram indicates the number of conodonts found per kilogram of sample; the bars are divided to show ratios between the genera Gondolella (line pattern), Streptognathodus (white), and Cavusgnathus (black). 


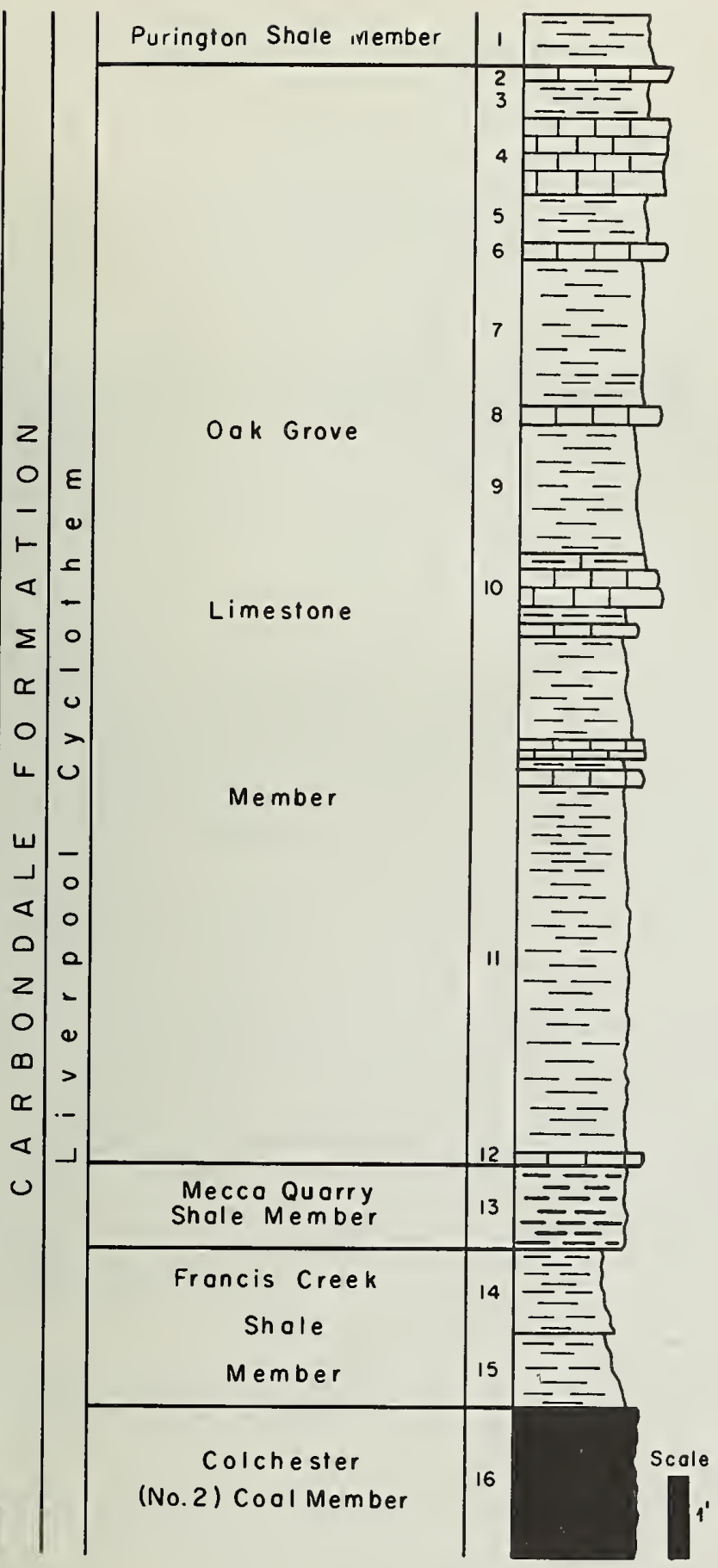

1. Shale - medium gray; contains flat ferruginous concretions; slightly fossiliferous.

2. "Cast band limestone" - tan; contains casts of pelecypods and gastropods.

3. Shale - dark gray, we11-bedded.

4. "Linoproductus limestone" - blue gray to rusty brown; contains abundant brachiopods, brachiopod spines, gastropods, and crinoidal debris.

5. Shale - dark gray, slightly fossiliferous.

6. Limestone - dark brownish gray, limonitic, lenticular; contains impressions of pelecypods.

7. "Dunbare1la shale" - dark gray, well-bedded; contains Dunbarella, Aviculopecten, and Lingula.

8. "Pelecypod limestone" - dark brownish gray, argillaceous; contains ostracods, Lingula, and Orbiculoidea.

9. "Mesolobus shale" - dark gray, calcitic, slightly fossiliferous; contains Mesolobus at base.

10. "Gray septarian limestone" - medium blue gray; nodular but forms nearly continuous bed; contains a thin shale parting; upper part contains Marginifera, Cornuspira, and Ammodiscus.

11. Shale - dark gray, becomes lighter in color upward, calcitic, thinbedded; the base contains pelecypod fragments, Ammodiscus, and some crinoidal debris.

12. "Crinoidal limestone" - medium gray, medium-grained, impure.

13. Shale - black, "slaty," hard; middle portion contains small phosphatic nodules giving pimple structure.

14. Shale - medium dark gray, soft, poorly laminated, burrowed, fossiliferous.

15. Shale - light gray, soft, fairly well laminated, slightly fossiliferous.

16. Coal - exposed at river level during low water.

Fig. 15 - WOLF COVERED BRIDGE, cutbank on Spoon River at Wolf Covered Bridge. NW $\frac{1}{4}$ NE $\frac{1}{4}$ Sec. 13, T. 10 N., R. 3 E., Knox County, Maquon Quadrangle. Conodont assemblages may be collected from the Mecca Quarry Shale Member of the Carbondale Formation. The macro-fauna alone merits a visit. The locality is a few miles east of Knoxville. Follow signs from U.S. Route 150 or Illinois Route 97. (Section taken from Smith et al., 1970.) 


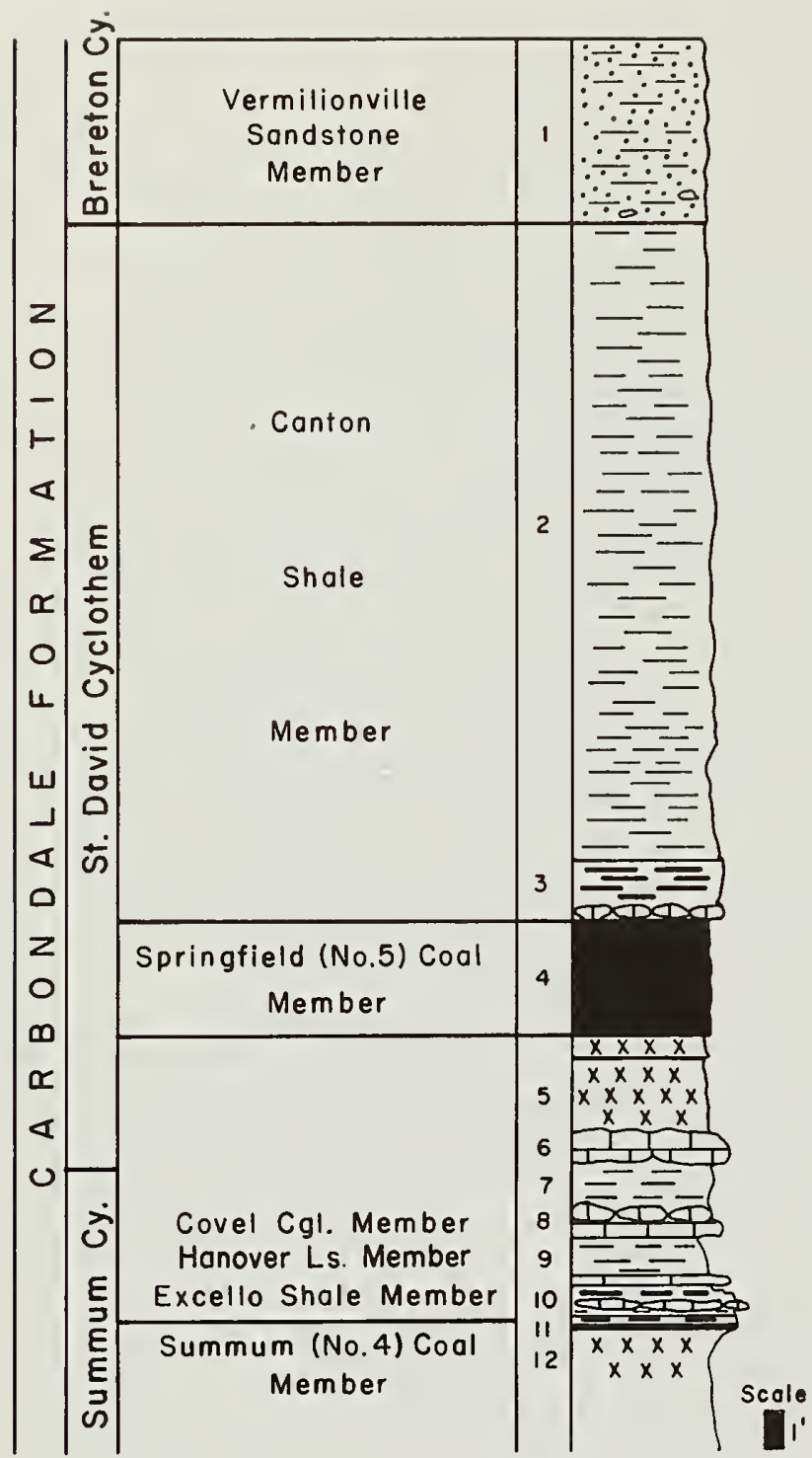

1. Sandstone - light tan, fine- to medium-grained, thin-bedded; contains a few concretions as in unit below; not generally exposed.

2. Shale - medium gray, weathers tan; somewhat silty; contains several argillaceous and calcitic concretions; contains a blocky band approximately $3^{\prime}$ from base.

3. Shale - black, well laminated, "slaty"; contains thin phosphatic lenses in bottom 1'. Zone of large dark gray, discoidal limestone nodules at base.

4. Coal - contains a 6" clay band 2" from base.

5. Clay - medium gray to medium dark gray.

6. Limestone - medium dark gray, mottled with light greenish gray; nodular, slightly silty and dolomitic.

7. Shale - medium dark gray to dark gray, smooth, laminated; contains limestone nodules.

8. Conglomerate - composed of rounded fine-grained limestone; upper surface encrusted by algae.

9. Shale - medium dark gray, mottled with light greenish gray; calcareous; contains a $0-1 \frac{1}{2} "$ thick limestone band containing abundant Ammodiscus.

10. Shale - dark gray to black, fissile; contains a 0-3" granular phosphatic band underlain by a thin spherulitic algal limestone bed.

11. No. 4 Coal position - black carbonaceous shale containing vitrain lenses.

12. Clay - light gray to greenish gray.

Fig. 16 - KICKAPOO CREEK, cutbank on Kickapoo Creek and in small tributary along road going west downhill from the entrance to Jubilee

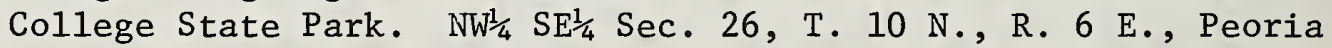
County, Elmwood Quadrangle. Section taken from Smith et al., 1970. Abundant conodonts, including Gondolella, are found in the nodular limestone of the Hanover Limestone Member (No. 9). To reach Jubilee College State Park, take the Brimfield exit of Interstate Route 74 into Kickapoo. Go west one mile on U.S. Route 150 for about a mile and follow Jubilee College sign. Road to Kickapoo Creek turns right near college. 


\begin{tabular}{|c|c|c|c|c|}
\hline \multirow{10}{*}{\multicolumn{2}{|c|}{ 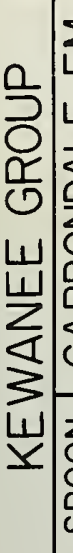 }} & OAK GROVE LS. MBR. & 1 & $\perp$ \\
\hline & & \multirow{2}{*}{$\begin{array}{l}\text { MECCA QUARRY } \\
\text { SHALE MEMBER }\end{array}$} & 2 & \\
\hline & & & 4 & \\
\hline & & \multirow{5}{*}{$\begin{array}{l}\text { FRANCIS CREEK } \\
\text { SHALE } \\
\text { MEMBER } \\
\\
5 \mathrm{FT} .\end{array}$} & 5 & \\
\hline & & & & \\
\hline & & & 6 & $\bar{E}$ \\
\hline & & & & $=$ \\
\hline & & & & \\
\hline & & COLCHESTER (NO. 2) COAL & 7 & \\
\hline & & & 8 & $\{\ldots \ldots \ldots\}$ \\
\hline
\end{tabular}

\section{4}

5. Shale - bluish gray, soft, non-

6. Shale - gray to light bluish gray, noncalcareous, thin-bedded.

7. Coal - shaly in lowermost part.

8. Clay - gray and purplish gray to dark bluish gray, noncalcareous, soft, sandy.

Fig. 17 - RHODES' (1952) LOCALITY 7, cutbank on South Fork Bear Creek. SE $\frac{1}{4}$ SW $\frac{1}{4}$ Sec. 9, T. 1 N., R. 6 W., Adams County, Camp Point Quadrangle. This is the topotype locality for Illinella. The section is commonly poorly exposed. Rhodes' natural assemblages came from the Mecca Quarry Shale Member of the Carbondale Formation. Section taken from notes of S. E. Ekblaw, 1930. 
1. Shale - dark gray to black, calcareous; contains numerous pelecypods.

2. Limestone - gray; contains numerous thin-shelled pelecypods.

3. Coal - bright, discontinuous.

4. Clay - light gray to dark gray; contains small limestone nodules.

5. Shale - greenish gray, calcareous, poorly bedded above, well bedded below; contains limestone concretions; very sandy in lower part.

6. Limestone - reddish, dense, nodular, poorly bedded, fossiliferous.

7. Shale - light bluish gray; contains greenish gray limestone concretions.

8. Shale - greenish gray, calcareous, micaceous, slightly fossiliferous; contains lens-like masses of calcareous sandstone.

9. Limestone - bluish gray to gray, crystalline, fossiliferous, nodular; weathers rusty brown.

10. Shale - greenish gray, calcareous, micaceous; contains ironstone concretions.

11. Limestone - greenish, brownish, and dark gray, crinoidal and fossiliferous.

12. Shale - greenish gray to dark gray, fossiliferous; contains limestone nodules.

13. Shale - dark gray; contains limestone concretions.

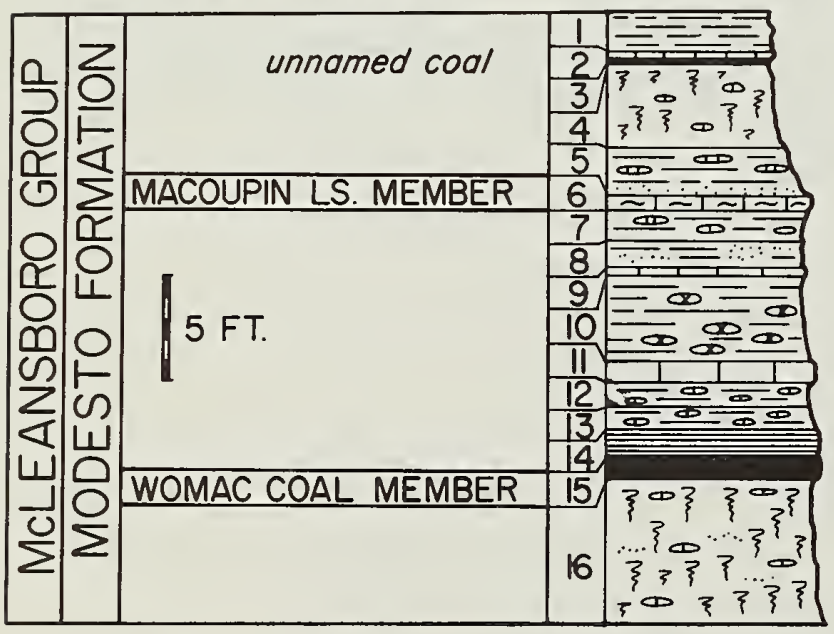

14. Shale - black, hard, laminated; contains conodont natural assemblages; lower inch dark gray and fossiliferous.

15. Coal - thin-bedded.

16. Clay - bluish to greenish gray, starchy, slightly sandy in places; contains calcareous nodules.

Fig. 18 - RHODES' (1952) LOCALITY 2, ravine 100 feet east of Illinois Route 4. SW $\frac{1}{4} S^{\frac{1}{4}}$ Sec. 34, T. $10 \mathrm{~N}$., R. $7 \mathrm{~W}$. or ravine 100 feet east of old

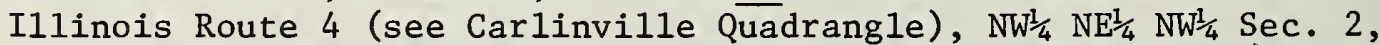
T. 9 N., R. 7 W., Macoupin County, Carlinville Quadrangle. Rhodes' natural assemblages were collected from the black shale above the Womac Coal Member of the Modesto Formation. (Stratigraphic section after Kosanke et al., 1970). 


\section{REFERENCES}

DuBois, E. P., 1941, Additional evidence on the origin of conodonts: Illinois Acad. Sci. Trans., v. 34, p. 168.

DuBois, E. P., 1943, Evidence on the nature of conodonts: Jour. Paleontology, v. 17, p. 155-159, p1. 25.

Kosanke, R. M., J. A. Simon, H. R. Wanless, and H. B. Willman, 1960, Classification of the Pennsylvanian strata of Illinois: Illinois Geol. Survey R. I. 214, 84 p., 1 plate.

Lane, H. R., 1967, Uppermost Mississippian and lower Pennsylvanian conodonts from the type Morrowan region, Arkansas: Jour. Paleontology, v. 41, p. 920-942, pls. 119-123.

Lane, H. R., G. K. Merrill, J. J. Straka II, and G. D. Webster, 1971, North American conodont biostratigraphy: Geol. Soc. America Memoir 127, p. 395-414.

Rhodes, F. H. T., 1952, A classification of Pennsylvanian conodont assemblages: Jour. Paleontology, v. 26, p. 886-901.

Scott, H. W., 1942, Conodont assemblages from the Heath Formation, Montana: Jour. Paleontology, v. 16, p. 293-300.

Smith, W. H., R. B. Nance, M. E. Hopkins, R. G. Johnson, and C. W. Shabica, et a1., 1970, Depositional environments in parts of the Carbondale Formation, western and northern Illinois: Francis Creek Shale and Mazon Creek biota: Illinois Geol. Survey Guidebook Series 8, 119 p.

Templeton, J. S., and H. B. Willman, 1963, Champlainian Series (Middle Ordovician) in Illinois: Illinois Geol. Survey Bull. 89, 260 p.

Willman, H. B., and others, 1967, Geologic map of Illinois $(1 / 500,000)$ : Illinois Geol. Survey Map.

Willman, H. B., and John C. Frye, 1970, Pleistocene stratigraphy of Illinois: Illinois Geol. Survey Bul1. 94, 204 p. 



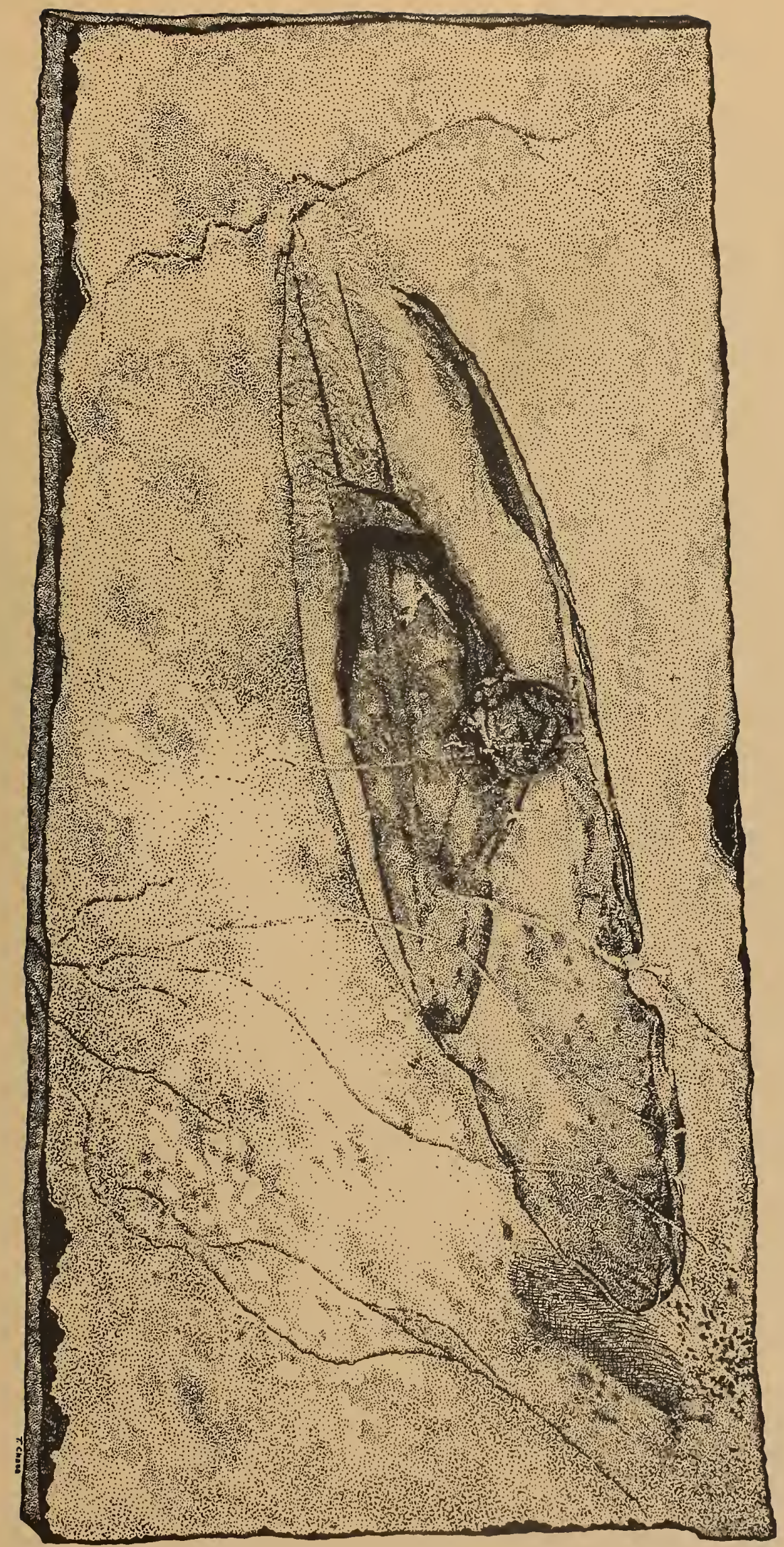

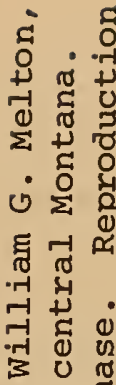

ते हो

ช

岂

14 0

0 y

त्र 동

टै ข

宫

兵 40

4ै 4

ㅇํำ

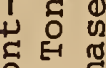

E

옹

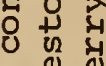

0 号 $E$

嵌今 حै

ट 它

苛

0 3

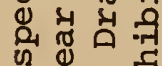

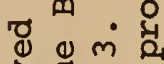

द्रा $x$ ते

ध

(1) है त्र त्र

है, 4ै

त

屯

$\infty$ 䓀 पू

4 造 祭

यद

일 0 얻

ने गे से

ब

$\begin{array}{llll}4 & 2 & -1 & 4 \\ 0 & 4 & 4 & 0 \\ 0 & 0 & -1 & 1\end{array}$ Q न्त 0 岳 
